\title{
New species of Annonaceae from the Neotropics and miscellaneous notes
}

\author{
P.J.M. Maas ${ }^{1}$, L.Y.Th. Westra ${ }^{1}$
}

Key words

Annona

Annonaceae

Duguetia

Guatteria

Neotropics

Pseudoxandra

Rollinia

taxonomy
Abstract In this paper six new Neotropical species in four genera are described, viz. Annona oxapampae, Duguetia vaupesana, Guatteria castilloi, G. pachyphylla, G. sanctae-crucis and Pseudoxandra xylopiifolia. Furthermore additional data on four poorly known species of Guatteria (G. denudata, G. glauca, G. modesta and G. terminalis) are added.

Published on 29 November 2010

\section{INTRODUCTION}

In 1992 Maas and Westra monographed the genus Rollinia in the framework of Flora Neotropica. In the years after that, molecular and morphological work made it clear that the genus Rollinia could not be maintained and should be incorporated into Annona. All the necessary nomenclatural combinations were recently published by Rainer (2007), who is currently monographing the genus Annona. A new species of Annona is described in the present paper which formerly would have fallen under the genus Rollinia.

After the revision of the genus Duguetia (2003) by Maas, Westra \& Chatrou no novelties had been discovered until now. In the present article, however, a new species from Amazonian Colombia is added.

Maas \& Westra revised the Neotropical genus Pseudoxandra (22 species) in 2003. In 2005 they added a 23rd species. Now another new species, only known from one collection from Amazonian Peru, is described.

The genus Guatteria is by far the largest genus of Annonaceae in the Neotropics with its approximately 300 species (Erkens et al. 2008). During the last years the former Utrecht Herbarium staff, PhD students, and graduate students were intensively involved in the research of this genus. This involved both phylogenetic (Erkens et al. 2007a, b) and revisionary work. The most recent Utrecht revisions of Guatteria dealt with Central America (Erkens et al. 2006, Erkens 2007), the Guianas (Scharf et al. 2005, 2006a, b, 2008), the Neotropics in general (Erkens et al. 2008), and generic delimitation (Erkens 2007, Erkens \& Maas 2008). In the near future a revision of the Amazonian species of Guatteria is planned, whereas the treatment of the Guianan species of the genus is under way. In the present article three additional species of Guatteria are described, whereas additional notes on four other species are given.

\footnotetext{
Netherlands Centre for Biodiversity Naturalis (section NHN), Biosystematics Group, Herbarium Vadense, Wageningen University, Generaal Foulkesweg 37, 6703 BL Wageningen, The Netherlands;

corresponding author e-mail: paul.maas@wur.nl.
}

\section{DESCRIPTION OF SPECIES}

1. Annona oxapampae Maas \& Westra, sp. nov. - Fig. 1-3; Map 1

Species foliis magnis pilis stellatis dense obtectis, monocarpiis semiconnatis recognoscenda. - Typus: Vásquez et al. 30476 (holo WAG; iso AMAZ, HOXA, HUT, MO, MOL, USM, WU), Peru, Pasco, Oxapampa, Distr. Huancabamba, Parque Nacional Yanachaga-Chemillén, near Quebrada Yanachaga, 2265 m, 21 Aug. 2004.

Tree 4-20 m tall; young twigs and petioles densely covered with appressed to erect, curved, simple and furcate, and some 3- or 4-armed stellate hairs to $1 \mathrm{~mm}$ long. Leaves: petiole $10-25 \mathrm{~mm}$ long, $2-3 \mathrm{~mm}$ diam; lamina elliptic, $16-33$ by $7-16$ $\mathrm{cm}$ (leaf index 1.7-2.3), chartaceous, brown above, pale green with brownish secondary veins and primary vein below, rather densely covered with appressed to erect, curved, simple and furcate, and some 3- or 4-armed stellate hairs to $1 \mathrm{~mm}$ long above, densely so below, base obtuse, apex acute, obtuse, rounded, or acuminate (acumen 15-20 mm long), secondary veins distinct, slightly curved, $12-15$ on either side of primary vein, angles with primary vein $45-65^{\circ}$, loop-forming, smallest distance between loops and margin $2-3 \mathrm{~mm}$, tertiary veins percurrent, distinct. Inflorescences together with leaves, or fruits on older leafless branchlets, supra-axillary to leafopposed, 2- or 3-flowered. Indument: pedicels and outer side of sepals and petals densely covered with curved, brown hairs; peduncle wanting; pedicels 10-25 mm long, 1.5-2 mm diam; bracts not observed or upper bract very inconspicuous, in lower 1/4th of pedicel. Flowers brown in vivo; sepals free, appressed, broadly ovate-triangular, $5-6$ by $5-6 \mathrm{~mm}$, not gibbous; corolla tube 5-6 mm high, c. $8 \mathrm{~mm}$ diam, wings oblong-elliptic, horizontal, 9-13 $\mathrm{mm}$ long, 5-7 mm high, 1.5-2 $\mathrm{mm}$ thick. Fruit subglobose to broadly ovoid, $3.5-6$ by $3-6$ $\mathrm{cm}$, yellow in vivo, black in sicco, carpels $50-100$, connate for about half of their length, free part broadly oblongoid, 5-7 $\mathrm{mm}$ long, densely covered with brown, curved, appressed, mostly simple hairs, apex obtuse, wall $0.5-1 \mathrm{~mm}$ thick. Seeds ellipsoid, $20-22$ by $8-10 \mathrm{~mm}$.

Distribution - Amazonian Peru (Pasco). 


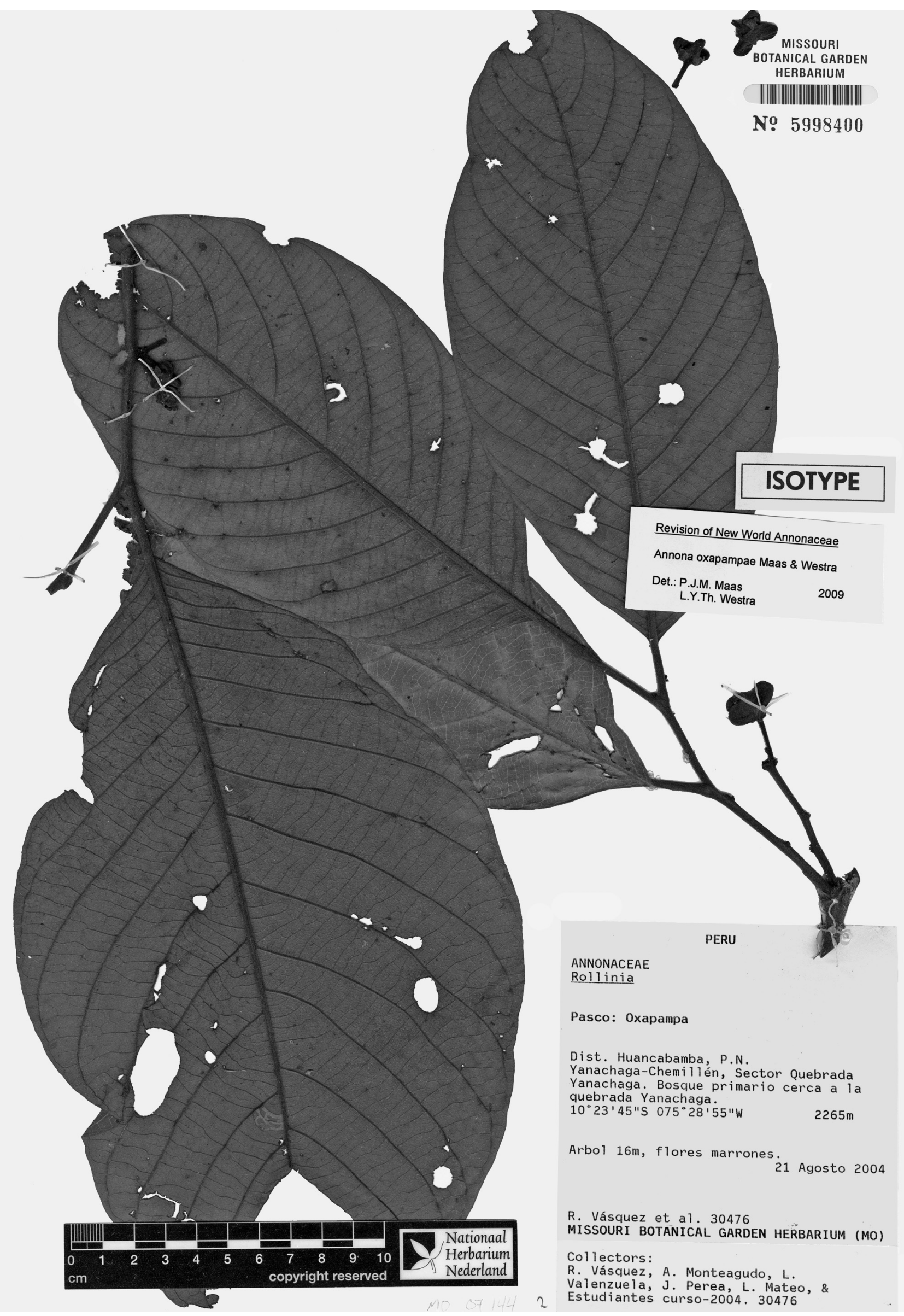

Fig. 1 Annona oxapampae Maas \& Westra. Flowering twigs (Vásquez et al. 30476, iso MO). 
Fig. 2 Annona oxapampae Maas \& Westra. Inflorescence (Cárdenas et al. 831, WAG).

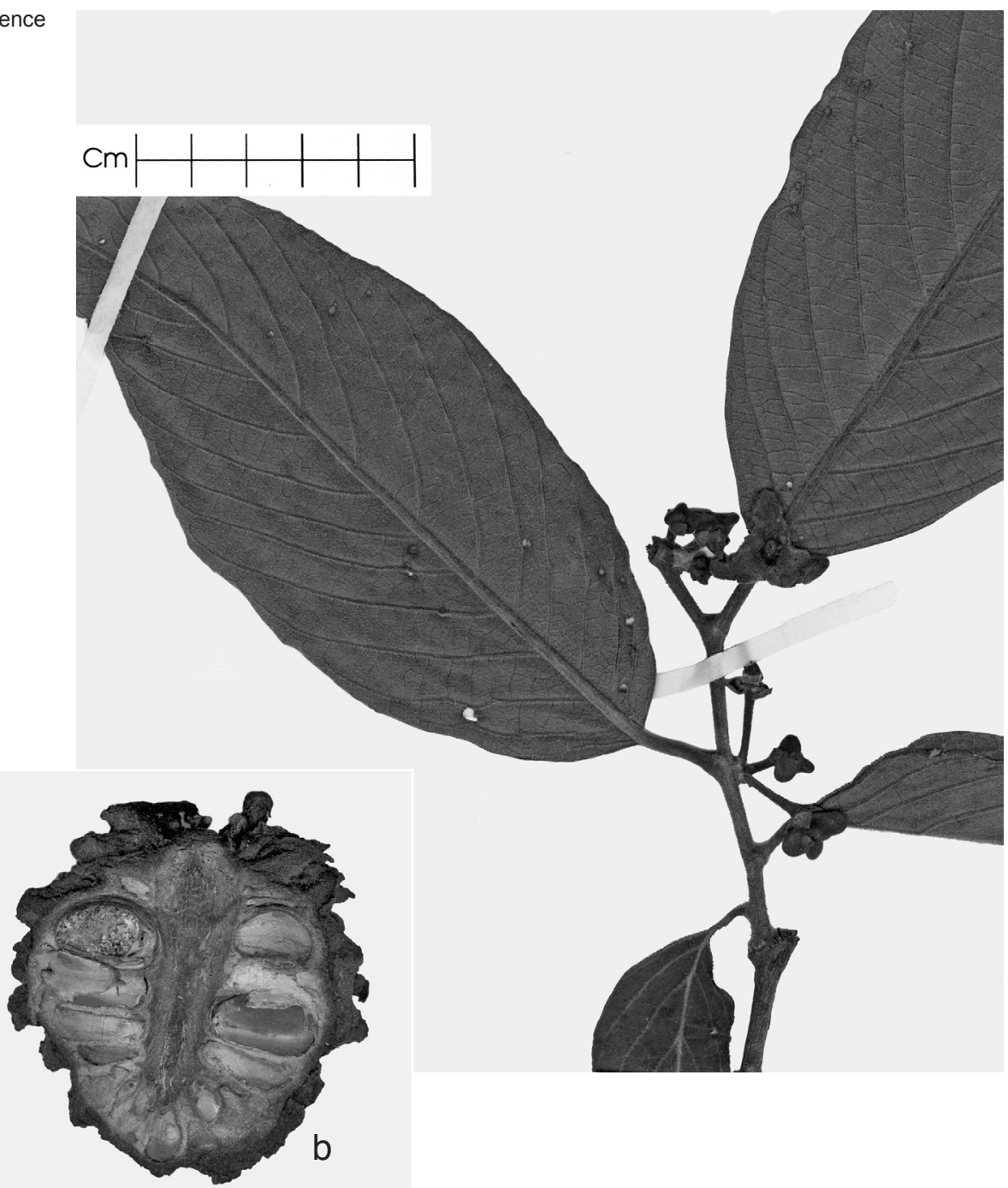

a
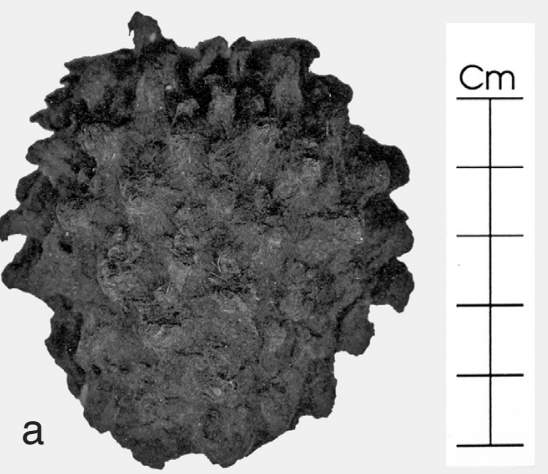

Revision of New World Annonaceae

Annona oxapampae Maas \& Westra

Det.: P.J.M. Maas

L.Y.Th. Westra

2009

Fig. 3 Annona oxapampae Maas \& Westra. a. Fruit seen from outside; b. longitudinal section of fruit (a, b: Perea \& Mateo 1688, WAG).

Habitat \& Ecology - In primary and secondary forest. At elevations of 2000-2300 m. Flowering: June, August; fruiting: August, September.

Note - Annona oxapampae falls within a group of species characterized by a winged corolla and formerly referred to the genus Rollinia (see Maas et al. 1992). From these species it is distinguished at first glance by the combination of very large and densely hairy leaves and a fruit composed of half-connate carpels.

Other specimens examined. PERU, Pasco, Oxapampa, Distr. Huancabamba, Sector San Daniel, 2171 m, Cárdenas et al. 831 (MO, WAG); Oxapampa, road from Oxapampa to Abra Villa Rica, 2270 m, Monteagudo et al. 6949 (MO, WAG); Oxapampa, Distr. Huancabamba, Quebrada Yanachaga, 2097 m, Perea \& Mateo 1688 (WAG); Oxapampa, Distr. Huancabamba, Parque Nacional Yanachaga-Chemillén, near Quebrada Yanachaga, $2250 \mathrm{~m}$, Vásquez et al. 28355 (MO), idem, 2265 m, Vásquez et al. 30470 (HOXA, MO, USM, WAG).

\section{Duguetia vaupesana Westra \& Maas, sp. nov. - Fig. 4;} Map 1

Ut videtur $D$. odoratae proxima sed differt foliorum laminis subtus pilis stellatolepidotis modice vel parce obtectis (nec laminis subtus pilis stellato-lepidotis vel lepidotis omnino obtectis), praeterea in genere distincta staminibus apice discoideis apiculis usque ad $0.5 \mathrm{~mm}$ longis ornatis. - Typus: Defler 12 (holo
COAH; iso MO), Colombia, Vaupés, Município de Taraira, Estación Biológica Caparú, $3 \mathrm{~km} \mathrm{~N}$ of Lago Taraira, plot C-7, tree no. 5, $1^{\circ} 00^{\prime} \mathrm{S}, 69^{\circ} 49^{\prime} \mathrm{W}, 200 \mathrm{~m}$, 23 March 1990.

Tree c. $23 \mathrm{~m}$ tall, c. $20 \mathrm{~cm}$ diam, bark light ochre with wavy, longitudinal furrows $1-2 \mathrm{~cm}$ across, $0.5-1 \mathrm{~cm}$ deep, no flakes; young twigs and petioles densely covered with brownish entire scales $0.2-0.5 \mathrm{~mm}$ diam. Leaves: petiole 5-7 mm long, 1-1.5 $\mathrm{mm}$ diam lamina narrowly elliptic, $10-16$ by $3-5 \mathrm{~cm}$ (leaf index $3-4)$, chartaceous, greyish green on both sides, slightly shiny and glabrous above, dull and rather densely to sparsely covered with whitish, intermixed with some light brown, stellate scales 0.1-0.4 mm diam below, base acute to shortly attenuate, apex acute to acuminate (acumen $10-15 \mathrm{~mm}$ long), primary vein impressed above, secondary distinct, veins curved, 10-12 on either side of primary vein, impressed above, loop-forming at almost right angles, loops distinct, shortest distance between loops and margin $2-5 \mathrm{~mm}$, angles with primary vein $60-80^{\circ}$, tertiary veins reticulate, raised above. Inflorescences among leaves, leaf-opposed, a single rhipidium, 1-flowered; peduncles 2-2.5 mm long, 2-2.5 mm diam, pedicels $20-23 \mathrm{~mm}$ long, $1-3$ $\mathrm{mm}$ diam; upper bract at c. 2/3 from base, transversely ovate, 2.5-3 mm long, amplexicaul. Indument: pedicels, outer side of bracts, sepals and petals totally covered with entire scales 


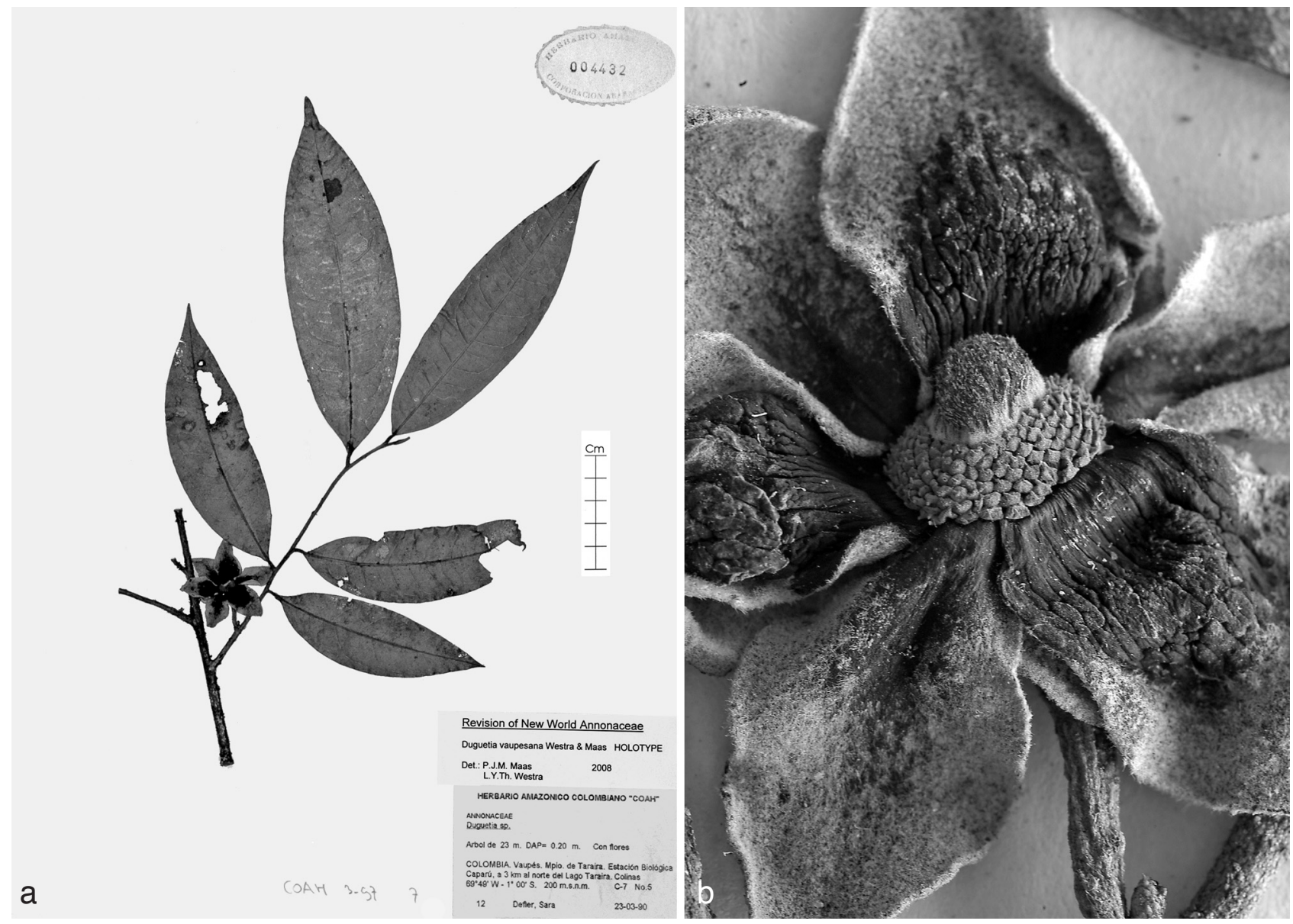

Fig. 4 Duguetia vaupesana Westra \& Maas. a. Flowering twig; b. detail of flower (a, b: Defler 12, holo COAH).

or stellate scales $0.1-0.5 \mathrm{~mm}$ diam, inner side of sepals totally covered with whitish (simple or stellate) hairs to c. $0.5 \mathrm{~mm}$ long, inner side of petals similar except for glabrous callose part; flower buds not seen; flower colour not recorded; sepals (almost) free, ovate, $15-17$ by $12-13 \mathrm{~mm}$, acute to obtuse; petals subequal, elliptic to obovate-elliptic, $15-30$ by $10-14$ $\mathrm{mm}$, acute to obtuse, inner base of inner petals callose; stamens numerous, 1.5-2 mm long, apex of connective discoid, $0.2-0.3$ by $0.6-0.7 \mathrm{~mm}$, densely covered with minute hairs, apiculate (apiculum $0.2-0.5 \mathrm{~mm}$ long). Carpels numerous, totally covered with whitish hairs to c. $0.2 \mathrm{~mm}$ long, stigmas filiform, 1-1.5 mm long, sparsely covered with hairs to c. 0.3 $\mathrm{mm}$ long. Fruit not seen.

Distribution - Amazonian Colombia (Vaupés).

Habitat \& Ecology — Upland habitat overlying Plio-Pleistocene red and yellow clays. At an elevation of c. 200 m. Flowering: March; fruiting: unknown.

Note - Duguetia vaupesana, only known from the type collection, seems most close to Duguetia odorata (Diels) J.F.Macbr., a widespread species in the upper Amazonian

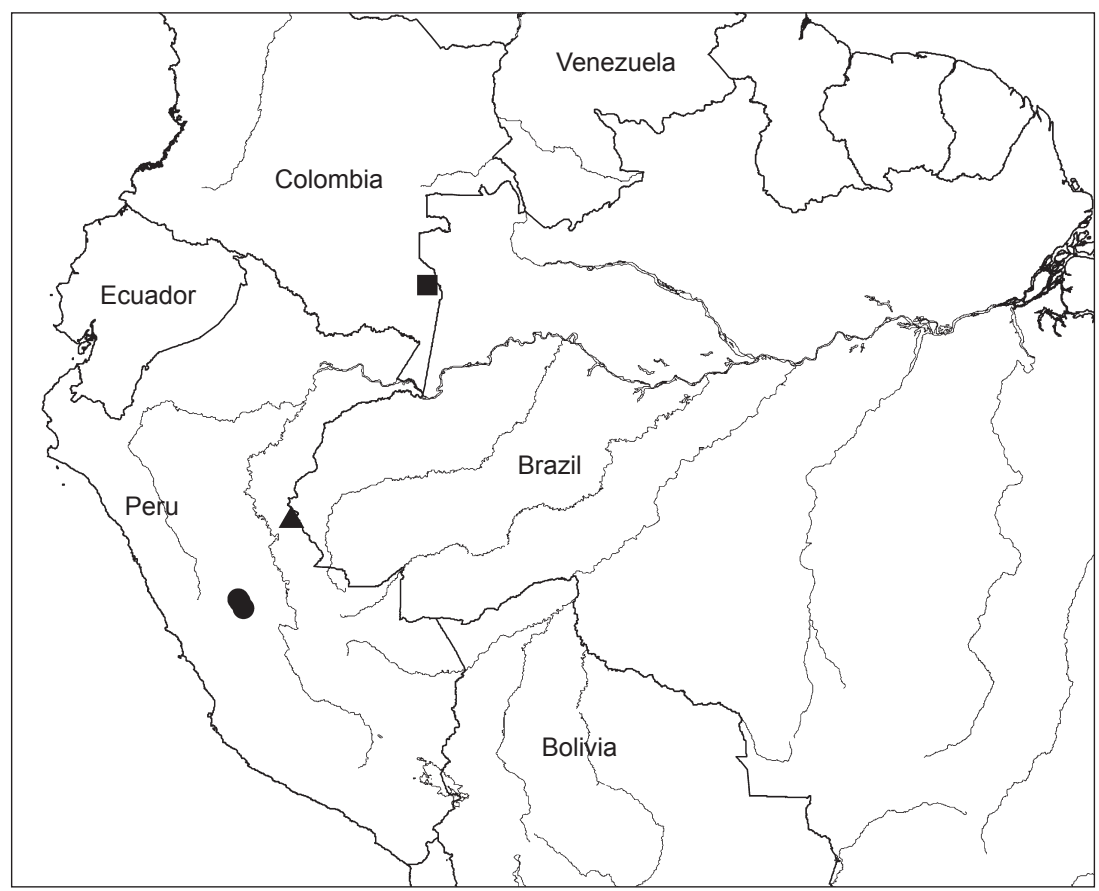

Map 1 Distribution of Annona oxapampae Maas \& Westra $(\bullet)$, Duguetia vaupesana Westra \& Maas (घ), and Pseudoxandra xylopiifolia Maas \& Westra (A). 


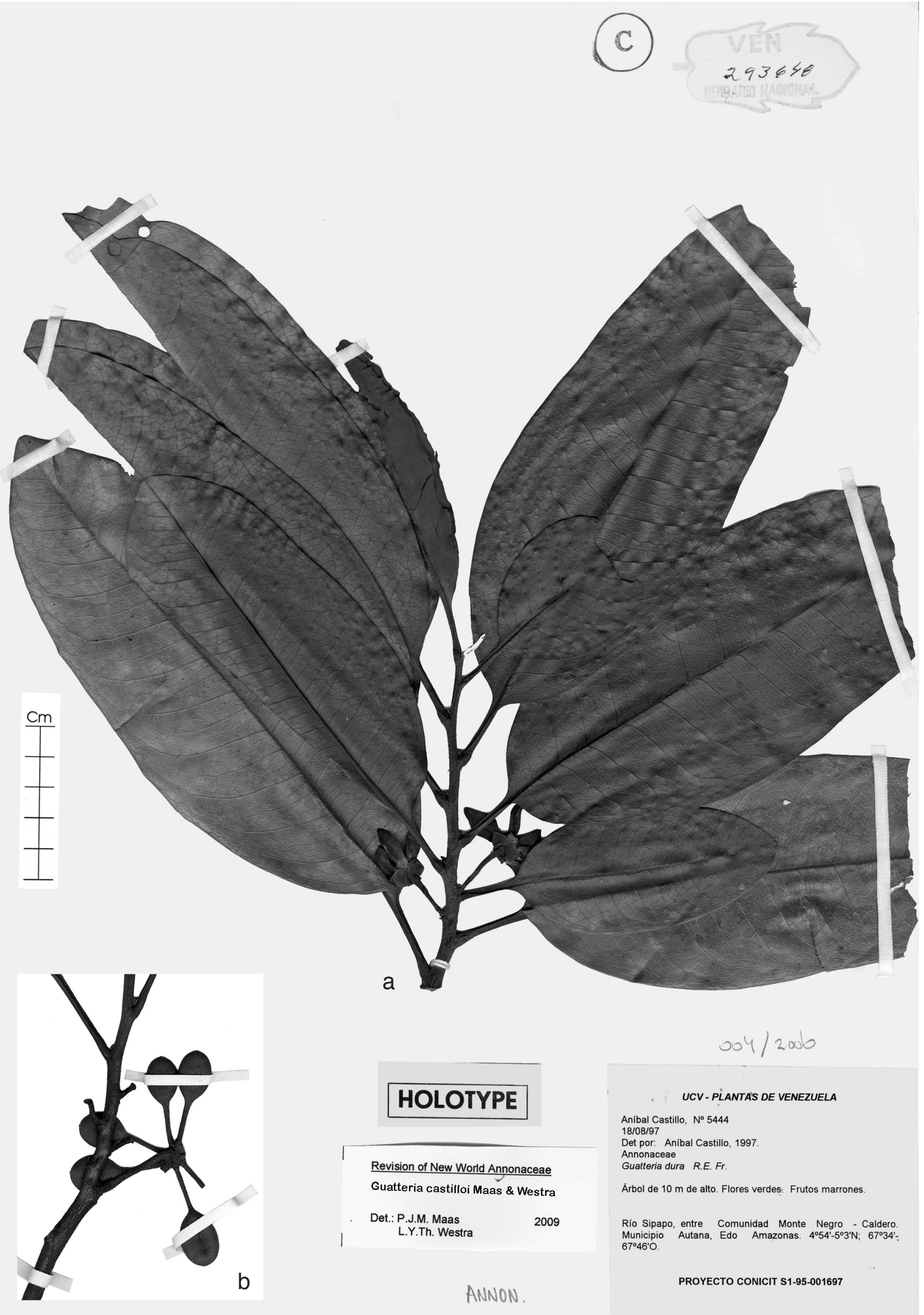

Fig. 5 Guatteria castilloi Maas \& Westra. a. Flowering twig; b. part of fruiting twig (a: Castillo S. 5444, holo VEN; b: Castillo S. 6848, VEN). 
region, but it differs by the distinctly less dense indument on the lower leaf side (in $D$. odorata: totally covered with stellate to entire scales). A remarkable feature of $D$. vaupesana are the apicula on the connective shields of the stamens. In more than half of the Duguetia species the apex of the connective is shieldlike, termed discoid (Maas et al. 2003), but normally without a distinct apiculum in the centre. Apart from in $D$. vaupesana, an apiculum is also found in $D$. lucida, but that species differs by, among other characters, a much denser indument of stellate scales on the lower leaf side (very densely or totally covered, vs rather densely to sparsely covered in $D$. vaupesana). For more variation in stamen shape see Maas et al. (2003: 13, fig. 8, and 209, fig. 78).

\section{Guatteria castilloi Maas \& Westra, sp. nov. - Fig. 5; Map 2}

Species foliis pro genere longe petiolatis, apice obtusis (vel breviter acuminatis), venatione reticulato prominente valde distincta. - Typus: Castillo S. 5444 (holo VEN; iso MO), Venezuela, Amazonas, Município Autana, Río Sipapo, between community Monte Negro and Caldero, 250 m, 18 Aug. 1997.

Tree 10-20 m tall; young twigs rather densely covered with appressed, white hairs, soon glabrous. Leaves: petiole $20-35 \mathrm{~mm}$ long, 1-2 mm diam; lamina narrowly oblong-elliptic to narrowly ovate, $12-19$ by $4-8 \mathrm{~cm}$ (leaf index $2.4-3.7$ ), coriaceous, not verruculose, shiny, greyish green to brown above, brown below, glabrous above, sparsely covered with appressed, white hairs below, base acute to obtuse, slightly attenuate, apex obtuse, sometimes shortly acuminate (acumen to $5 \mathrm{~mm}$ long), margins somewhat revolute, primary vein impressed above, secondary veins distinct, $13-15$ on either side of primary vein, strongly prominent above, smallest distance between loops and margin 1-2 $\mathrm{mm}$, tertiary venation prominent above, strongly reticulate. Flowers solitary, in leafy zone; pedicels $15-20 \mathrm{~mm}$ long, $1 \mathrm{~mm}$ diam, fruiting pedicels c. $22 \mathrm{~mm}$ long, 1-2 mm diam, sparsely covered with appressed, white hairs, articulated at 1/4-1/5 from the base, with 3-5 soon falling bracts, upper bract c. $5 \mathrm{~mm}$ long; flower buds not seen; sepals rigid, free, broadly ovate-triangular, $5-6$ by $5-6 \mathrm{~mm}$, appressed, margins somewhat revolute, outer side sparsely covered with appressed hairs; petals green in vivo, equal, narrowly oblong-elliptic, $13-20$ by $5-8 \mathrm{~mm}$, outer side rather densely to sparsely covered with appressed hairs; stamens c. $2 \mathrm{~mm}$ long, connective shield papillate. Monocarps c. 10 , green in vivo, brown in sicco, ellipsoid, $13-15$ by $7-10$ $\mathrm{mm}$, sparsely covered with appressed hairs, apex apiculate (apiculum < $0.2 \mathrm{~mm}$ long), wall c. $1.5 \mathrm{~mm}$ thick, stipes 10-12 by $1 \mathrm{~mm}$. Seed not studied (abortive?).

Distribution - Venezuela (Amazonas).

Habitat \& Ecology - Black water flooded forest ('bosque ribereño, influenciado por aguas negras'). At elevations of c. $250 \mathrm{~m}$. Flowering: August, October; fruiting: October.

Note - Guatteria castilloi is unique by the combination of petioles long for the genus, a prominent, reticulate leaf venation and a mostly obtuse leaf apex. This species is dedicated to Dr. Aníbal Castillo-Suárez, active and inspiring director of the Fundación Instituto Botánico de Venezuela, Caracas (VEN).

Other specimens examined. VenezuelA, Amazonas, Município Autana, Río Sipapo, from Barranco Colorado to mouth of Río Autana, $262 \mathrm{~m}$, Castillo S. 6848 (MO, VEN); Município Autana, Río Sipapo, from desecho Tonina to Pozo Tonina, 250 m, Castillo S. 6960 (MO, VEN).

\section{Guatteria denudata R.E.Fr. - Fig. 6; Map 3}

Guatteria denudata R.E.Fr. (1957) 601. - Type: Schultes \& Cabrera 17374 (holo S; iso US), Colombia, Vaupés, Río Piraparaná, tributary of Río Apaporis, headwaters of Caño Teemeeña, 10 Sept. 1952.

Small $(1.5 \mathrm{~m})$ to medium tree; young twigs sparsely covered with appressed hairs to glabrous, or very soon glabrous. Leaves: petiole 5-15 mm long, 1-2 mm diam; lamina elliptic to narrowly elliptic, or narrowly oblong-elliptic, $7-15$ by $3-6 \mathrm{~cm}$ (leaf index 1.7-2.8), coriaceous, not verruculose, shiny and dark brown above, brown below, glabrous above and below, base obtuse, the extreme base obtuse to slightly attenuate, apex acuminate (acumen 10-20 mm long), primary vein impressed above, secondary veins indistinct, $12-15$ on either side of primary vein (hardly countable), slightly raised above, tertiary veins reticulate, flat to slightly prominent above, smallest distance between loops and margin $2-5 \mathrm{~mm}$. Flowers solitary, in axils of leaves; pedicels 6-12 mm long, c. $1 \mathrm{~mm}$ diam, articulated at c. 1/5 from the base, rather densely covered with appressed, brownish hairs to glabrous, bracts 4 or 5 , soon falling; flower buds not seen; sepals free, broadly ovate-triangular, $3-4$ by $4-5 \mathrm{~mm}$, appressed, outer side sparsely covered with appressed hairs; petals green in vivo, subequal, narrowly oblong-elliptic, 10-15 by $4-8 \mathrm{~mm}$, outer base densely covered with appressed hairs,

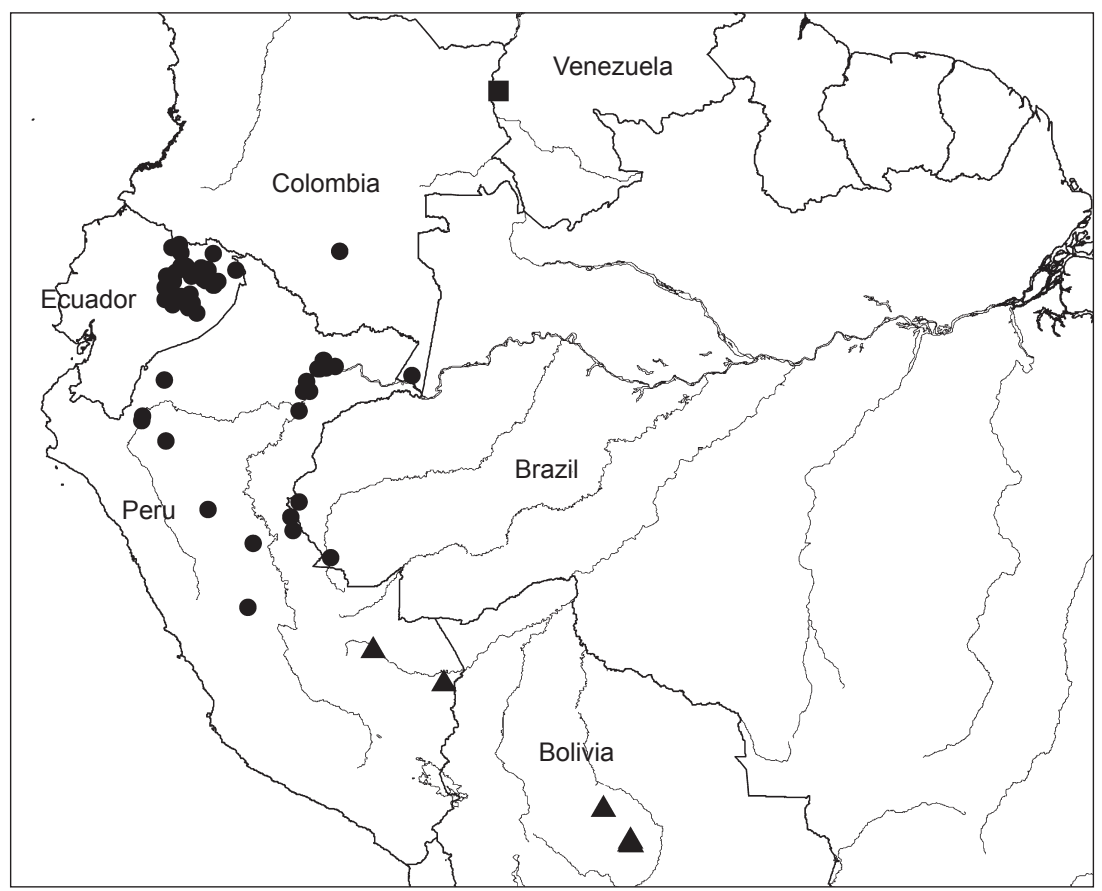

Map 2 Distribution of Guatteria modesta Diels (-), Guatteria castilloi Maas \& Westra (ם), and Guatteria sanctaecrucis Maas \& Westra $(\boldsymbol{\Delta})$. 


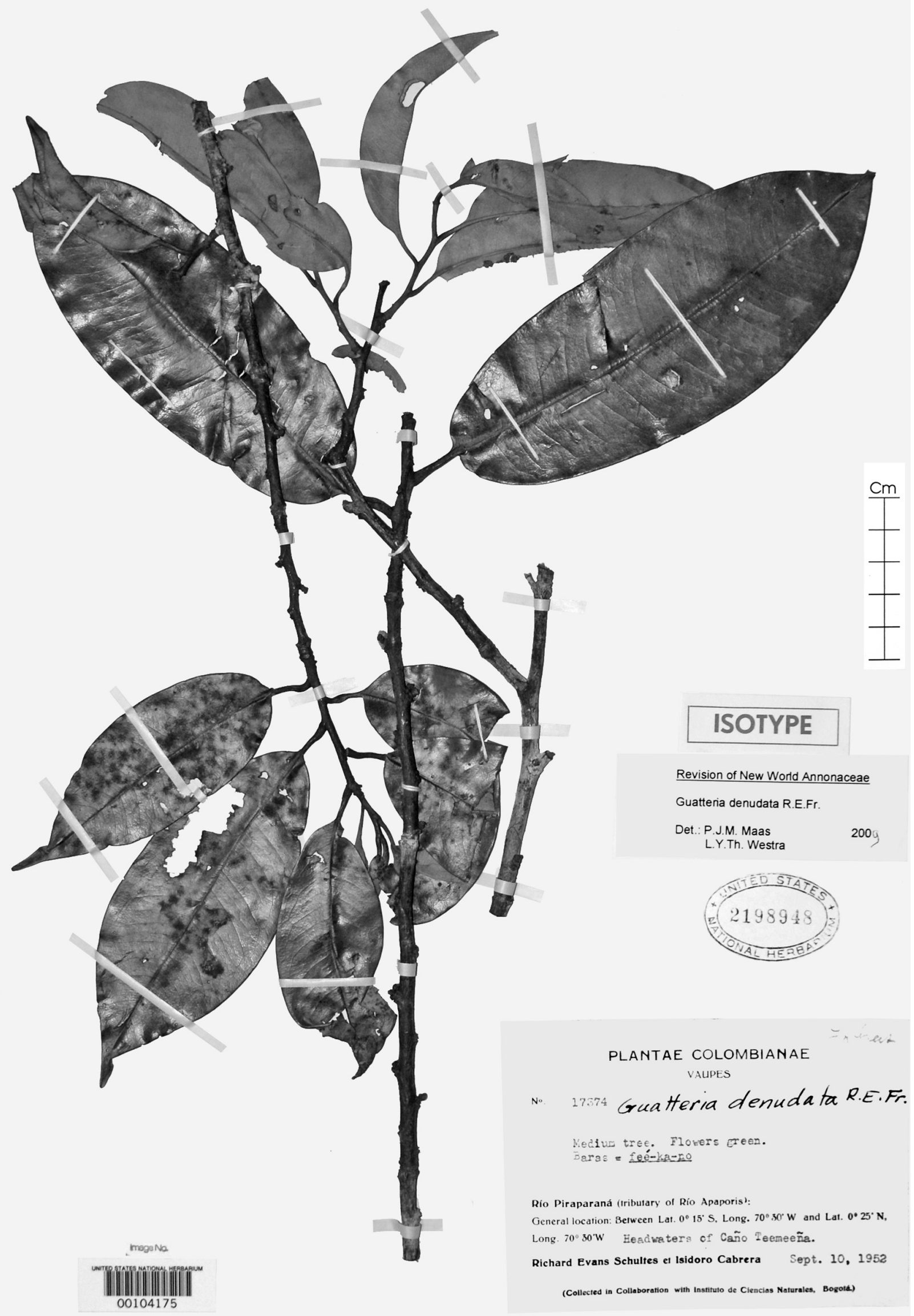

Fig. 6 Guatteria denudata R.E.Fr. Flowering twig (Schultes \& Cabrera 17374, iso US). 

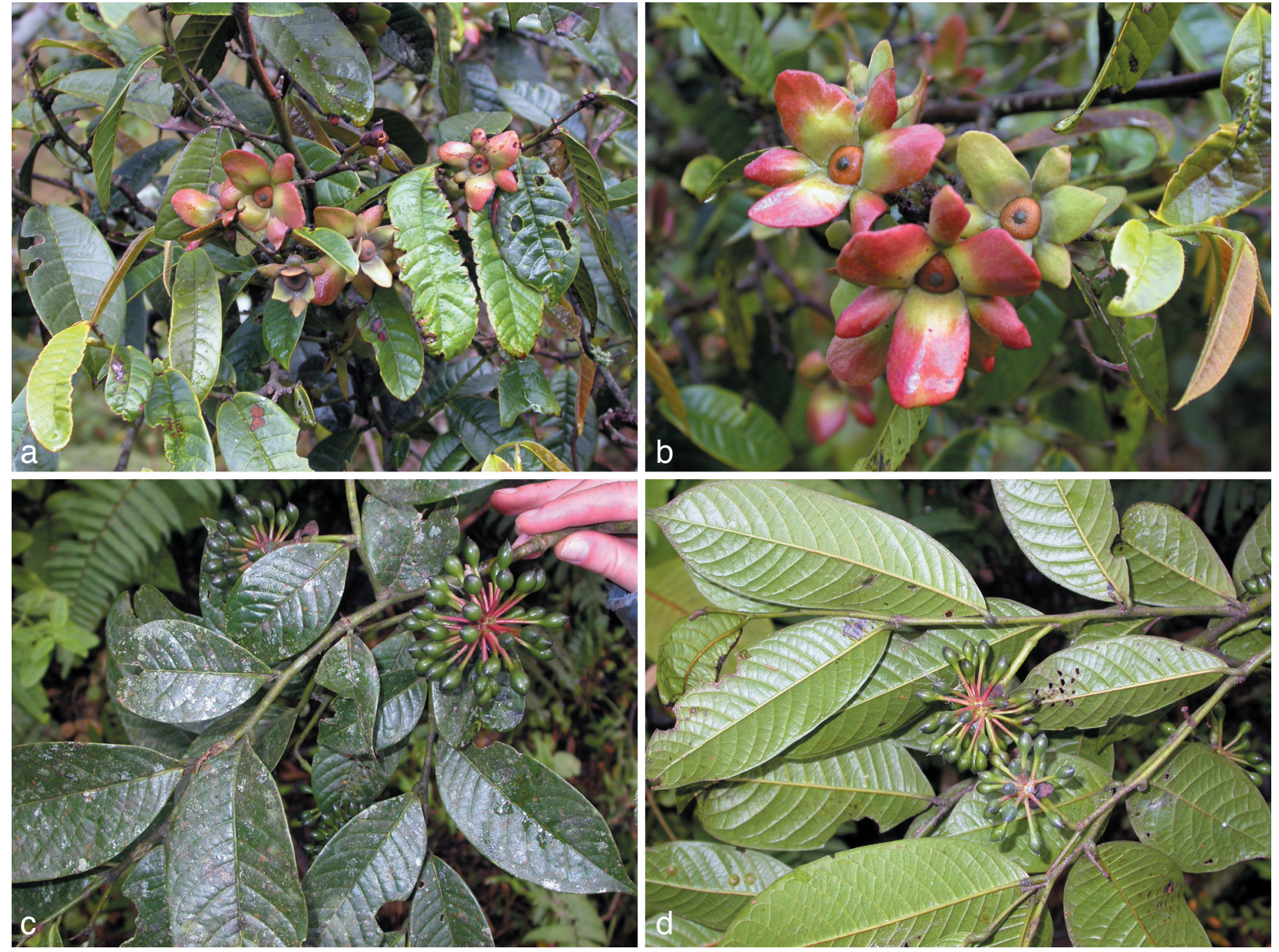

Plate 1 Guatteria glauca Ruiz \& Pav. a. Flowering branch; b. flowers; c, d. fruiting branch (a, b: Homeier et al. 2367, GOET; c, d: Homeier et al. 2600, GOET).
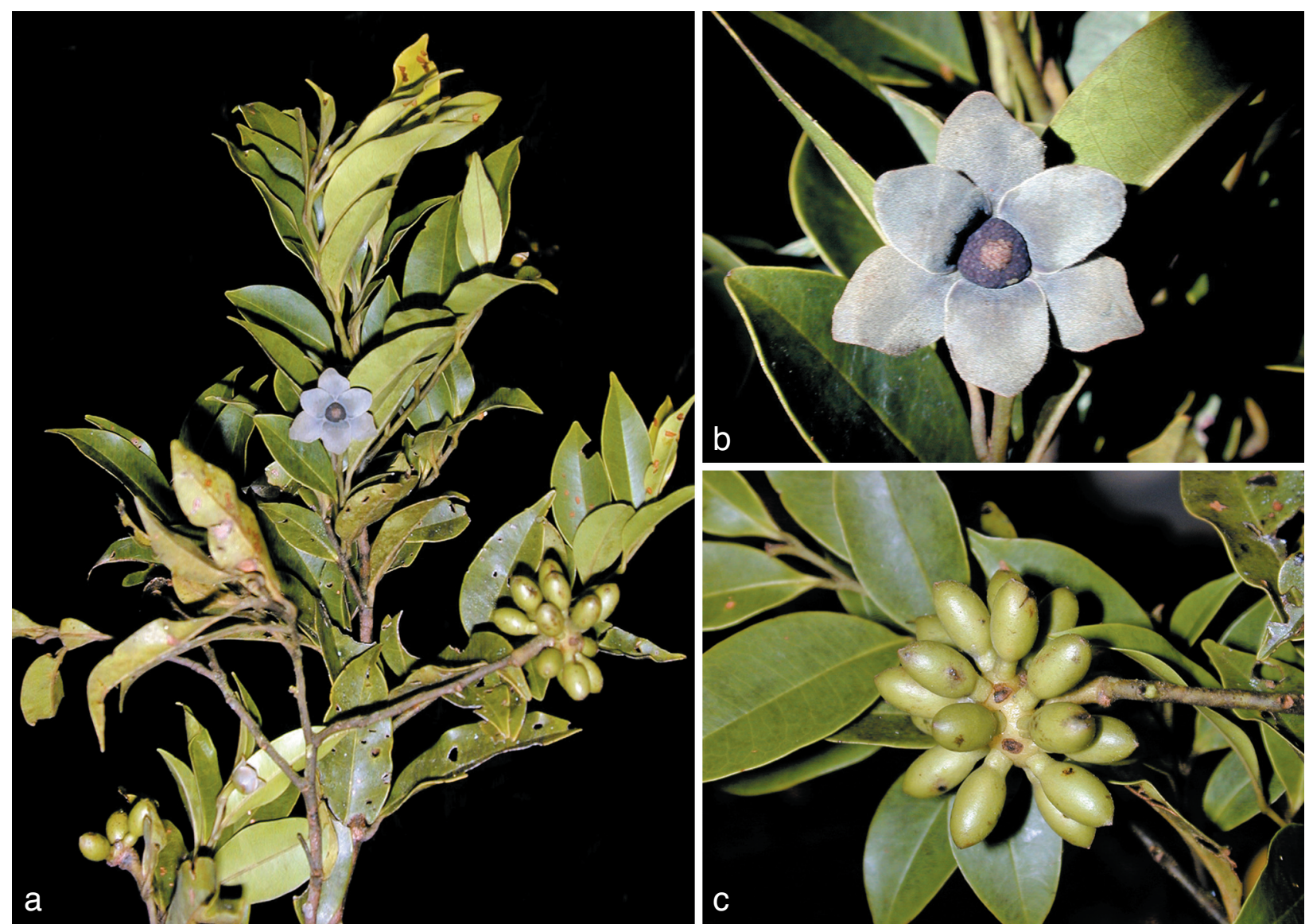

Plate 2 Guatteria terminalis R.E.Fr. a. Flowering and fruiting branch; b. flower; c. fruit (Farfán et al. 995, CUZ). 
otherwise sparsely; stamens 1.5-2 mm long, connective shield papillate. Monocarps not seen.

Distribution - Amazonian Colombia.

Habitat \& Ecology - Vegetation type unknown. At about sea level. Flowering: September; fruiting: unknown.

Vernacular names - Colombia: Feé-ka-no (Baras) (Schultes \& Cabrera 17374).

Note - Guatteria denudata (included by R.E. Fries in sect. Pteropus) is a poorly known species from 2 gatherings only. It is quite noteworthy by its very thick, shiny, glabrous leaves with an obtuse and slightly attenuate base.

Other specimen examined. ColomBIA, Vaupés, Río Piraparaná, tributary of Río Apaporis, Cerro E-ree-eé-kö-mee-ö-kee, Schultes \& Cabrera 17542 (US).

\section{Guatteria glauca Ruiz \& Pav. - Plate 1; Map 3}

Guatteria glauca Ruiz \& Pav. (1798) 145. - Type: Ruiz s.n. (syn B, BR, F, G, HAL, K, NY, P), Peru, Huánuco, "in nemoribus versus Cochero et Chinchao".

Guatteria coeloneura Diels (1906) 408, syn. nov. - Type: Weberbauer 3548 (holo B, 3 sheets; iso F, S), Peru, Huánuco, SW of Monzón, 1600 m, 8 Aug. 1903.

Guatteria pleiocarpa Diels (1906) 409, syn. nov. - Type: Weberbauer 4530 (holo B, 3 sheets; iso F, GH), Peru, Loreto, Moyobamba, 800-900 m, 17 Aug. 1904.

Guatteria juninensis R.E.Fr. (1938) 716, syn. nov. - Type: C. Schunke 267 (holo F, 2 sheets), Peru, Junín, Schunke Hacienda, above San Ramón, 1400-1700 m, 8-12 June 1929.

Guatteria lasiocalyx R.E.Fr. (1939) 388, syn. nov. - Type: Bang 583 (holo UPS; iso BM, C, E, F, K, L, M, MO, S, U, US, W), Bolivia, La Paz, Yungas, anno 1890.

Guatteria buchtienii R.E.Fr. (1939) 388, syn. nov. - Type: Buchtien 699 (holo S; iso US), Bolivia, La Paz, Mapiri Region, San Carlos, 850 m, Dec. 1926.

Guatteria rhamnoides R.E.Fr. (1939) 389, syn. nov. - Type: Krukoff 5707 (holo S; iso BM, K, MO, NY, RB, U, US), Brazil, Acre, Basin of Rio Purus, near mouth of Rio Macauhan, tributary of Rio Yacu, 27 Aug. 1933.

Tree, or rarely a shrub 1-28 m tall, up to $45 \mathrm{~cm}$ diam; young twigs and petioles densely covered with appressed to semierect or less often erect brownish hairs, soon glabrous. Leaves: petiole 5-13 mm long, 2-4 mm diam; lamina elliptic, narrowly elliptic, or oblong-elliptic, $9-25$ by $3-10 \mathrm{~cm}$ (leaf index 2.3-3.5(-5)), coriaceous or thinly coriaceous, rarely chartaceous, slightly shiny to dull, greyish to greyish brown or brown above, greenish brown or brown below, not verruculose, densely covered with appressed hairs in juvenile stage and soon glabrous (except on veins) above, rather densely to sparsely covered with appressed hairs mainly on veins below, base obtuse to acute, apex mostly acuminate (acumen 5-15 $\mathrm{mm}$ long), or acute, primary vein impressed above, secondary veins distinct, 12-20 on either side, distinctly impressed above, smallest distance between loops and margin $1.5-3 \mathrm{~mm}$. Flowers in a 1-2(-3)-flowered inflorescence, in axils of leaves or on branchlets after leaf fall, solitary; flower buds broadly to very broadly ovoid, apex obtuse, acute or acuminate; pedicels $10-20(-32) \mathrm{mm}$ long, $1.5-2 \mathrm{~mm}$ diam, fruiting pedicels to $25(-40) \mathrm{mm}$ long, to $4 \mathrm{~mm}$ diam, articulation at 1/5-1/2 from the base, densely covered with appressed (to semierect or erect) brownish hairs, becoming glabrous in age, bracts 4 or 5 , upper bract ovate, to $5 \mathrm{~mm}$ long, all bracts soon falling; sepals broadly to shallowly ovate or triangular-ovate, basally connate to at last \pm free, rarely totally connate or almost so, and tearing apart, 5-10 mm long, appressed, outer side densely covered with erect, brown hairs; petals green, yellow, cream, to white in vivo, slightly unequal, obovate, narrowly obovate, to flabellate, $13-25$ by $7-15 \mathrm{~mm}$, outer side densely covered with appressed, brown hairs; stamens 1-1.5 mm long, connective shield glabrous. Monocarps 40-70, green, maturing black in vivo, black in sicco, ellipsoid, $7-13$ by $5-10 \mathrm{~mm}$, apex obtuse to apiculate (apiculum to $0.5 \mathrm{~mm}$ long), wall $0.1-0.6 \mathrm{~mm}$ thick, often on a conspicuously enlarged receptacle, stipes $6-17$ by $1-1.5 \mathrm{~mm}$. Seed ellipsoid, $8-12$ by $5-6 \mathrm{~mm}$, brown-grey to brown, surface smooth, slightly rugose, or pitted.

Distribution - Bolivia (Beni, Cochabamba, La Paz, Pando, Santa Cruz), Brazil (Acre), Ecuador (Esmeraldas?, MoronaSantiago, Napo, Zamora-Chinchipe), Peru (Amazonas, Cajamarca, Cuzco, Huánuco, Madre de Dios, Oxapampa, Pasco, San Martín).

Habitat \& Ecology - Mostly in montane or premontane cloud forest. At elevations from 150-2800 m; Flowering and fruiting: throughout the year.

Vernacular names - Bolivia: Chia (De Michel et al. 590), Chirimoya del monte (De Michel et al. 590), Chocolatillo negro (Smith et al. 13252, 13749), Laurel macho (De Walt et al. 121), Maurel canelón (Endara s.n.), Midha dhahua (Tacana) (Bourdy 1740, De Walt et al. 121, and Serato 58), Palo pancho verde (Serato 58), Piraquina (Guillén \& Roca 2494), Piraquina de

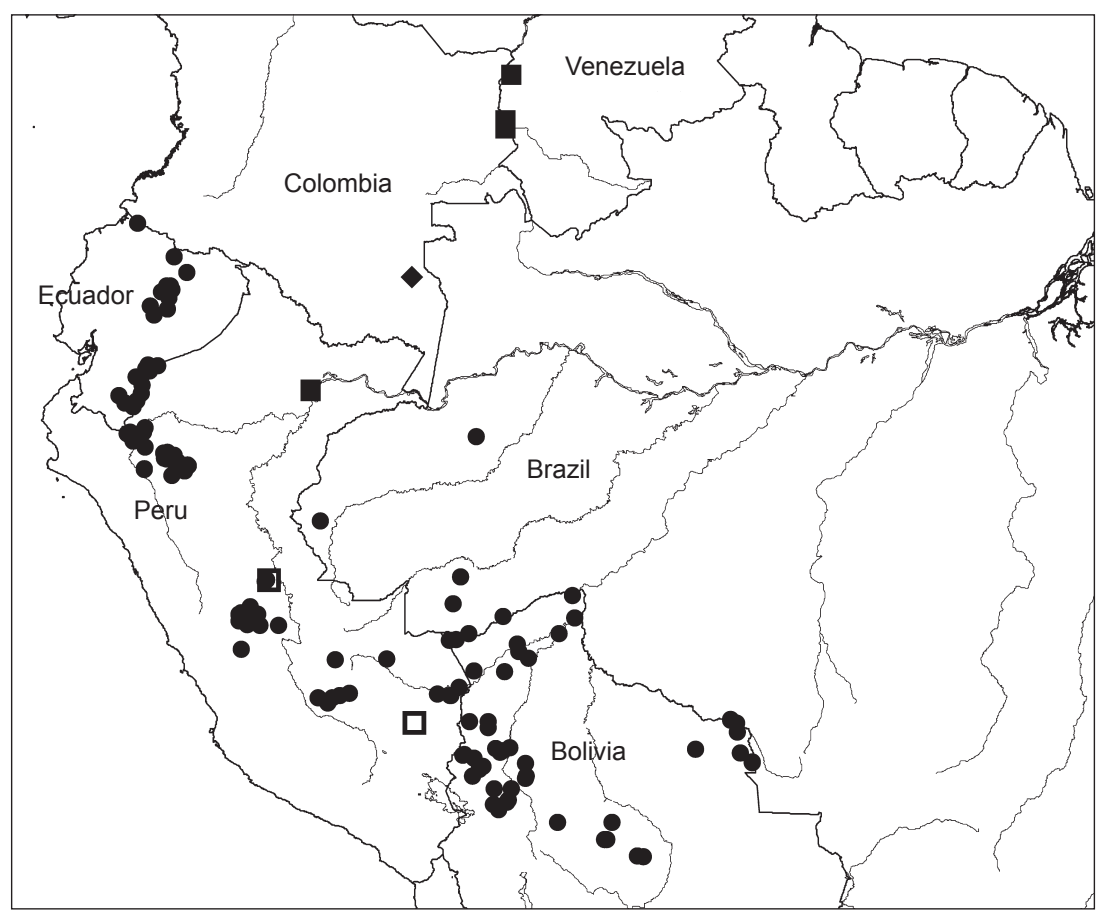

Map 3 Distribution of Guatteria denudata R.E.Fr. $(\boldsymbol{\nabla})$, Guatteria glauca Ruiz \& Pav. (๑), Guatteria pachyphylla Maas \& Westra (ם) and Guatteria terminalis R.E.Fr. ( $\square$ ). 


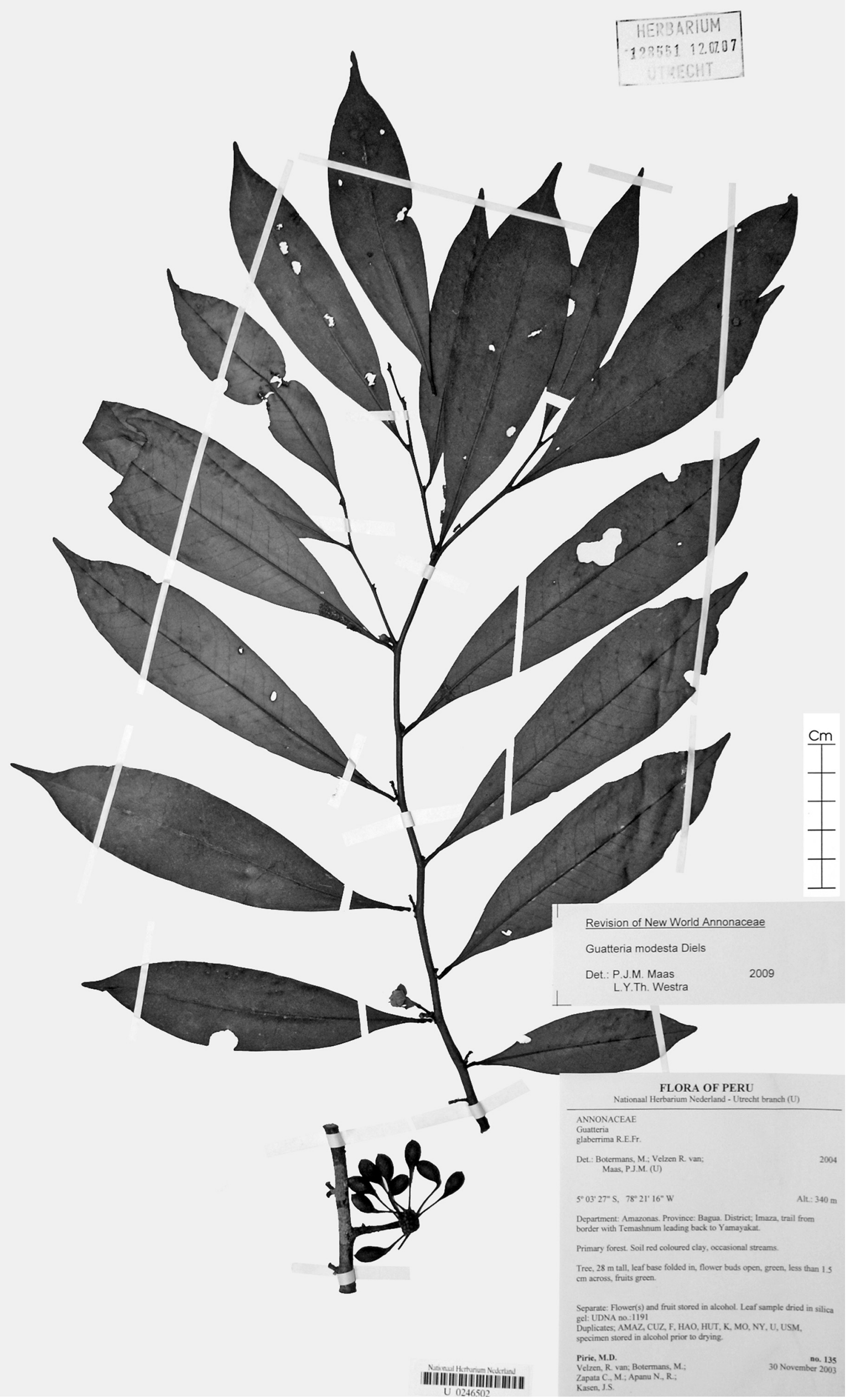

Fig. 7 Guatteria modesta Diels. Flowering and part of fruiting twig (Pirie 135, U). 
barbecho (Meneces 2087), Piraquina negra (Quevedo et al. 920, D.N. Smith et al. 14128). - Brazil: Envira fofa (Daly et al. 6878), Invireira (Campbell et al. 9694). - Ecuador: Fanicho (Cofán name) (Cerón 20901), Muraya (Shuar name) (Neill \& Manzanares 13144). - Peru: Amarillo (D.N. Smith \& Pretel 1491, 1549), Carahuasca negra (Gutiérrez R. et al. 206), Wámpuyais (Kayap 395), Yais (Díaz et al. 7230).

Notes - Until rather recently we had identified all material of this species as $G$. lasiocalyx R.E.Fr. When preparing the treatment of Annonaceae for the 'Catalógo de las Plantas vasculares de Bolivia' (Jörgensen et al. in prep.), we found out that there occurred a highly variable species in Bolivia, characterized by connate sepals and by secondary veins which are strongly impressed on the upper side of the lamina. Several species appeared to share these characters, namely G. buchtienii R.E.Fr., G. pleiocarpa Diels, G. rhamnoides R.E.Fr. and G. lasiocalyx R.E.Fr. After examining many specimens which had been identified as one of these species we found ourselves unable to draw sharp limits between them, which led us to consider the whole as a single complex species and treat them all as probable synonyms of $G$. lasiocalyx R.E.Fr. (the oldest name then available).

A few years later, during a visit of the first author to the Berlin Herbarium, he found various collections of G. glauca Ruiz \& Pav., which is the lectotype of the genus Guatteria (see Van Setten \& Maas 1990: 676-677). Guatteria glauca had been very poorly known so far, but in our opinion there is not any doubt that it is conspecific with $G$. lasiocalyx, clearly sharing the characters mentioned above. In Berlin he also found the types of $G$. coeloneura Diels and G. juninensis R.E.Fr. which equally appeared to fall within the complex. As a result of this research all seven species included by Robert Fries in Guatteria sect. Guatteria are synonymized under Guatteria glauca.

\section{Guatteria modesta Diels - Fig. 7; Map 2}

Guatteria modesta Diels (1924) 139; R.E.Fr. (1939) 430. — Type: Tessmann 3476 (holo B, 2 sheets; iso G, NY, S, US), Peru, Ucayali, Yarina Cocha, 150 m, 27 Dec. 1923.

Guatteria chlorantha Diels (1924) 139; R.E.Fr. (1939) 422, f. 14 d, syn. nov. - Type: Tessmann 3423 (holo B; iso G, NY, S, US), Peru, Ucayali, Yarina Cocha, 150 m, 7 Dec. 1923

Guatteria geminiflora R.E.Fr. var. geminiflora (1939) 421, syn. nov. - Type: Tessmann 4314 (holo B, 2 sheets; iso NY), Peru, Amazonas, mouth of Río Santiago, 160 m, 16 Oct. 1924.

Guatteria puncticulata R.E.Fr. (1939) 511, f. 33b-c, syn. nov. — Type: Krukoff 8225 (holo S; iso BM, F, K, MO, NY, U, US), Brazil, Amazonas, Mun. São Paulo de Olivença, near Palmares, Sept.-Oct. 1936.

Guatteria glaberrima R.E.Fr. (1947) 3, syn. nov. - Type: Lugo 237 (holo S; iso S, US), Ecuador, Pastaza, Mera, 25 Apr. 1940

Tree 8-55 $\mathrm{m}$ tall, up to $1 \mathrm{~m}$ diam, sometimes with buttresses up to $80 \mathrm{~cm}$ high; young twigs often black, sparsely covered with appressed hairs, soon glabrous. Leaves: petiole $5-10 \mathrm{~mm}$ long, c. $1 \mathrm{~mm}$ diam; lamina narrowly obovate to narrowly elliptic, $7-19$ by $2-6 \mathrm{~cm}$ (leaf index $3-5.3$ ), chartaceous to coriaceous, not to densely verrucose, blackish brown, brown to greyish brown above, brown to dark brown below, glabrous above, sparsely or rarely rather densely covered with appressed hairs to glabrous below, the primary vein sometimes covered with long hairs, margins glabrous or sometimes covered with long hairs, base long-attenuate and margins strongly rolled inwards, apex shortly acuminate (acumen 5-10 mm long), primary vein impressed above, prominent and often keeled below, secondary veins indistinct, 10-18 on either side of primary vein, flat to slightly prominent above, smallest distance between loops and margin 2-3 mm. Flowers solitary or in pairs; pedicels 10-25 mm long, 1-2 $\mathrm{mm}$ diam, fruiting pedicels to c. $3 \mathrm{~mm}$ diam, sparsely or rarely rather densely covered with appressed hairs to glabrous, articulated at $1 / 4-1 / 5$ from the base, with
4 or 5 bracts below articulation, 2 uppermost bracts obovate and enveloping young flower bud, to c. $5 \mathrm{~mm}$ long, soon falling, other bracts (very) broadly ovate, to c. $1 \mathrm{~mm}$ long, soon falling; flower buds depressed ovoid; sepals free, deltate, $3-9$ by $3-6$ $\mathrm{mm}$, appressed, finally reflexed, outer side densely covered with appressed hairs; petals green, maturing cream to yellow in vivo, equal, narrowly oblong-elliptic, $15-30$ by $4-13 \mathrm{~mm}$, outer side densely covered with appressed hairs; stamens 1-2 mm long, connective shield papillate or glabrous. Monocarps 10-50, green, maturing black in vivo, black in sicco, ellipsoid, 9-15 by $6-10 \mathrm{~mm}$, surface somewhat wrinkled when ripe, glabrous, apex rounded, wall $0.5-1 \mathrm{~mm}$ thick, stipes $8-20$ by c. $1 \mathrm{~mm}$. Seed ellipsoid, $8-11$ by $5-7 \mathrm{~mm}$, dark brown, pitted.

Distribution - Brazil (Acre, Amazonas), Colombia (Amazonas), Ecuador (Morona-Santiago, Napo, Pastaza, Sucumbios), Peru (Amazonas, Huánuco, Loreto, Madre de Dios, Pasco, Ucayali).

Habitat \& Ecology — In non-inundated lowland rain forest or submontane forest, often on red soil. At elevations of $100-$ $1250 \mathrm{~m}$. Flowering: throughout the year; fruiting: July to January.

Vernacular names - Brazil: Chaporoasca (Daly et al. 7729). - Ecuador: Caracaspi (Freire \& Inmunda 3210 and H. Vargas et al. 569), Fandicho (Cofán) (Cerón 21161), Gañitahuemo (Huaorani) (Aulestia \& Gonti 1752), Homñetahue (Huaorani) (Espinoza \& Coba 617), Minudawa (Huaorani) (King et al. 975); Oñetahue (Huaorani) (Aulestia et al. 1445), Oñitahue (Huaorani) (Aulestia et al. 3041), Runa caspi (Freire at al. 3392), Uñetahue (Huaorani) (Gudiño et al. 824), Uñitahue (Huaorani) (Aulestia \& Bainca 3551). - Peru: Carahuasca (Aróstegui V. 127 and Aspajo V. 15), Carahuasca negra (Reyna R. 62), Espintana hoja ancha (Soria S. 11), Wampuyais (Kayap 850), Yais (Huambisa) (C. Díaz et al. 7390); Yam yais (Huambisa) (Tunqui 194), Yeis (Huambisa) (Huashikat 2161), Yumi yeis (Huambisa) (Huashikat 879).

Notes - Guatteria modesta contains some of the largest trees within the genus, reaching a height of up to $55 \mathrm{~m}$ and a diameter up to $1 \mathrm{~m}$ ! By contrast, most Guatterias are small to medium trees, only relatively few species have been reported as tall trees with a trunk up to $50 \mathrm{~cm}$ diam. Guatteria modesta can easily be recognized by its long-attenuate, often narrowly obovate leaves, which have a quite dark colour when dry.

Various specimens from Ecuador (Pastaza, Sucumbios), Peru (Amazonas, Loreto, Ucayali), and Brazil (Acre, Amazonas) (marked in the Identification List as Gua modp) fall within the concept of $G$. puncticulata. They differ from typical G. modesta in having densely verruculose leaves with the margins and the primary vein (on the lower side) often covered with long hairs. As the differences were not absolute and several intermediate forms were found, we have included this species in G. modesta.

\section{Guatteria pachyphylla Maas \& Westra, sp. nov. - Fig 8;} Map 3

Foliis anguste obovatis, brevissime acuminates vel obtusis, coriaceis et monocarpiis distincte apiculatis facile recognoscenda. - Typus: Vásquez et al. 465 (holo MO; iso U), Peru, Loreto, Prov. Maynas, Puerto Almendras, Río Nanay, above lquitos, 120 m, 22 Aug. 1980.

Tree 10-24 m tall; young twigs glabrous. Leaves: petiole 6-15 $\mathrm{mm}$ long, $1-3 \mathrm{~mm}$ diam; lamina narrowly obovate, $10-21$ by 3-7 cm (leaf index 2.4-3.3), coriaceous, not verruculose, brown above and below, glabrous on both sides, base attenuate, basal margins slightly rolled inwards, apex very shortly and bluntly acuminate (acumen 1-4 mm long) or obtuse, primary vein impressed above, sharply keeled below, secondary veins indistinct, $12-15$ on either side of primary vein, flat to slightly impressed above, tertiary veins reticulate, flat to impressed 


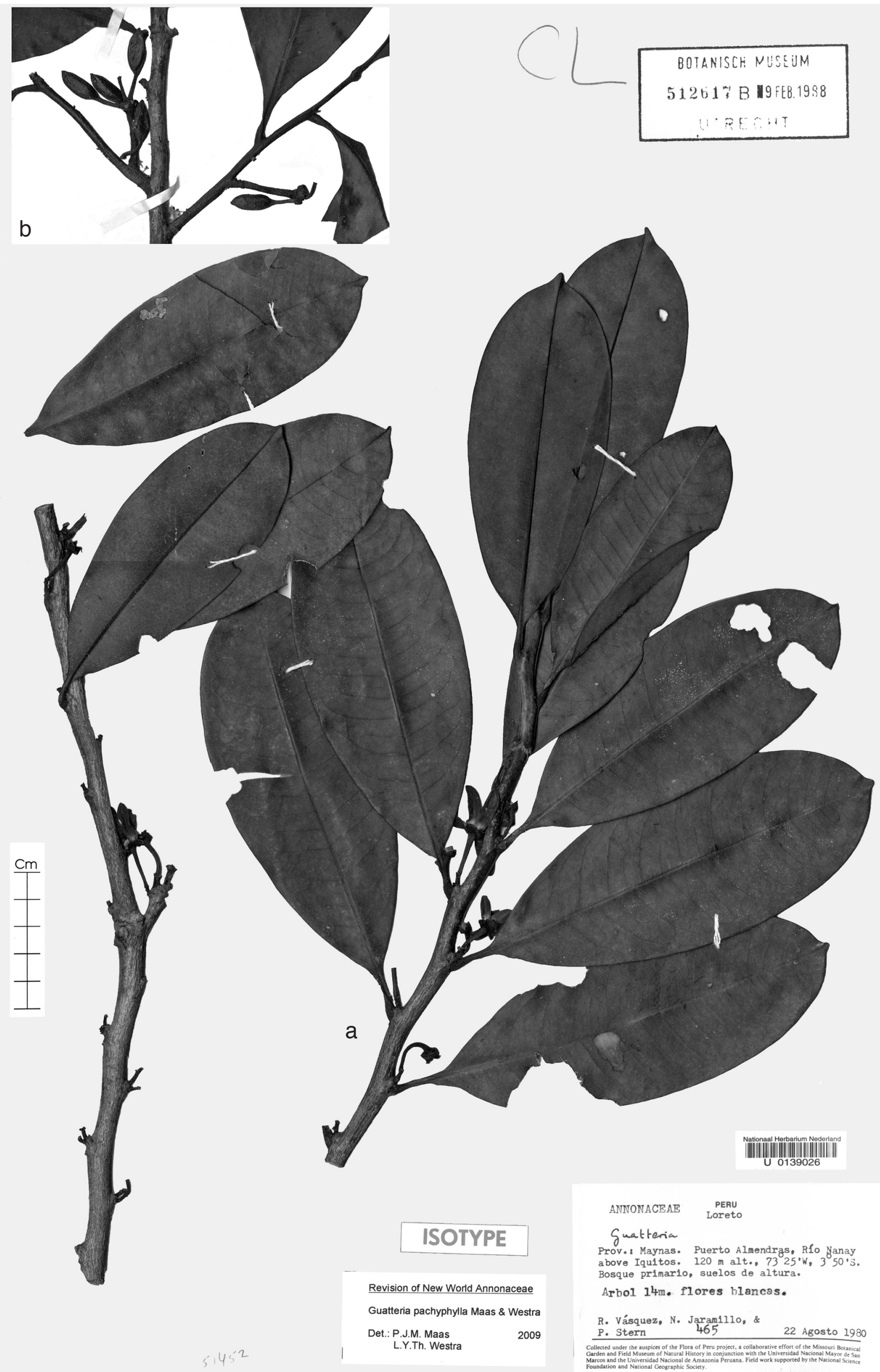

Fig. 8 Guatteria pachyphylla Maas \& Westra. a, Flowering twig; b. part of fruiting twig (a: Vásquez et al. 465, iso U; b: Stergios et al. 11488, U). 
above, smallest distance between loops and margin 3-4 mm. Flowers solitary or in pairs in axils of leaves or on older leafless branches; pedicels $15-20 \mathrm{~mm}$ long, c. $1 \mathrm{~mm}$ diam, fruiting pedicels 20-25 mm long, c. $2 \mathrm{~mm}$ diam, glabrous, articulated at $1 / 6-1 / 4$ from the base, bracts $5-7$, soon falling, upper bracts c. 3 by $2 \mathrm{~mm}$; flower buds broadly ovoid; sepals basally connate, broadly ovate-triangular, $4-5$ by $6-7 \mathrm{~mm}$, patent, but apically reflexed, outer side glabrous, but apex densely covered with curly hairs; petals white to yellow in vivo, subequal, narrowly oblong-elliptic, $11-20$ by $4-6 \mathrm{~mm}$, outer side rather densely to sparsely covered with crisped, erect and patent hairs; stamens c. $1 \mathrm{~mm}$ long, connective shield glabrous. Monocarps 10-25, black in sicco, narrowly ellipsoid, $12-16$ by $4-6 \mathrm{~mm}$, glabrous, apex distinctly pointed (apiculum c. $1 \mathrm{~mm}$ long), wall c. $0.2 \mathrm{~mm}$ thick, stipes $4-8$ by $1 \mathrm{~mm}$. Seed narrowly ellipsoid, 12-14 by 4-6 $\mathrm{mm}$, shiny black, longitudinally ridged.

Distribution - Amazonian Peru (Loreto), Venezuela (Amazonas).

Habitat \& Ecology — In non-inundated or temporarily inundated forest, on clayey to sandy soil. At elevations up to c. $120 \mathrm{~m}$. Flowering: August, September; fruiting: January.

Note - Guatteria pachyphylla is one of the most distinctive species in Guatteria because of its Clusia-like, coriaceous, narrowly obovate leaves, which have a very shortly acuminate apex (acumen to $4 \mathrm{~mm}$ long) and of which the lamina has impressed tertiary veins. Moreover, the monocarps are distinctly and sharply pointed. It looks superficially similar to the rarely collected Guyanan species G. clusiifolia D.M.Johnson \& N.A.Murray, sharing most leaf characters, but from that species it differs by much smaller monocarps (12-16 vs $22 \mathrm{~mm}$ long), which are, moreover pointed in the presently described species and which are obtuse in G. clusiifolia.

Other specimens examined. PERU, Loreto, vicinity of Iquitos, $120 \mathrm{~m}$, Revilla 3626 (MO, U); Prov. Maynas, Puerto Almendras, Río Nanay, $122 \mathrm{~m}$, Vásquez \& Jaramillo 5530 (U). - Venezuela, Amazonas, Município Autana, Río Cuao, between Caño Samariapo and Caño Grulla, Castillo S. 5157 (VEN); Dep. Atabapo, 15 km SE of San Fernando de Atabapo, near 'EI Pozo', in experimental zone of CVG-Proyecto Caucho, $110 \mathrm{~m}$, Stergios et al. 11488 (MO, PORT, U)

8. Guatteria sanctae-crucis Maas \& Westra, sp. nov. - Fig. 9; Map 2

Foliis pro ratione longis et angustis, venis secundariis a margine conspicue (vulgo 4-7 mm) remotis facile recognoscenda. - Typus: Nee 37331 (holo LPB; iso MO, NY, U), Bolivia, Santa Cruz, Prov. Ichilo, Parque Nacional Amboro, along Río Saguayo, 1.5-3 km NE of entrance into first Andean foothills, 375 m, 21 Dec. 1988.

Tree 8-25 m tall, to $47 \mathrm{~cm}$ diam; young twigs rather densely to sparsely covered with erect, brown hairs, soon glabrous. Leaves: petiole 5-7 mm long, 1-2 mm diam; lamina narrowly oblong-elliptic, $20-35$ by $4-8 \mathrm{~cm}$ (leaf index $3.6-5.2$ ), chartaceous, not verruculose, grey to greyish brown above, pale brown below, glabrous (except for some hairs along primary

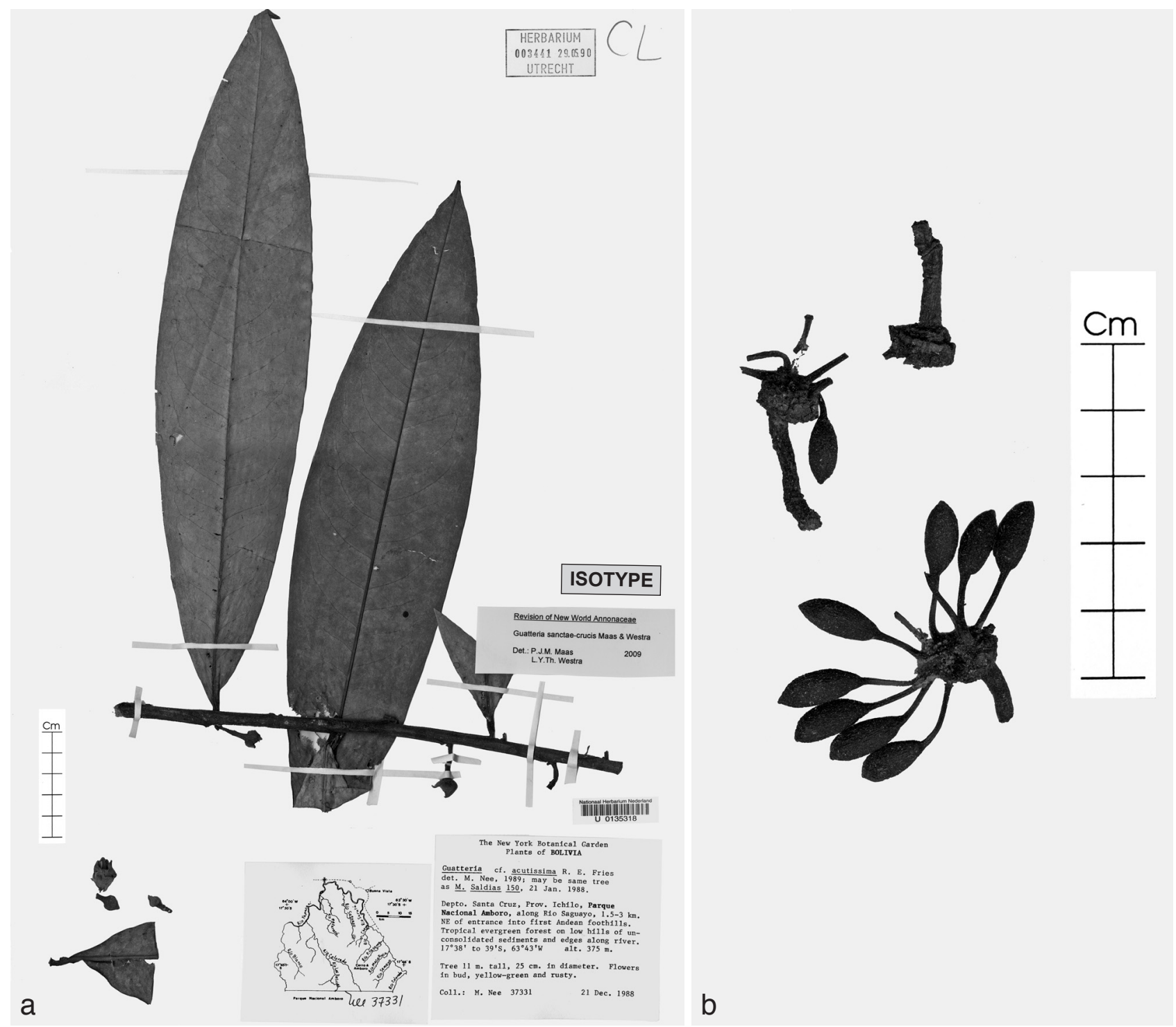

Fig. 9 Guatteria sanctae-crucis Maas \& Westra. a. Part of flowering twig; b. fruits (a: Nee 37331, iso U; b: Neill \& Quevedo 9357, U). 
vein) above, sparsely (the primary vein to densely so) covered with appressed and erect, whitish hairs below, base acute, apex shortly acuminate (acumen c. $5 \mathrm{~mm}$ long) to acute, primary vein impressed above, secondary veins distinct, 15-22 on either side of primary vein, slightly prominent above, smallest distance between loops and margin 4-7 mm. Flowers solitary or in pairs in axils of leaves or on older leafless branches; pedicels 18-20 $\mathrm{mm}$ long, $1.5-2 \mathrm{~mm}$ diam, fruiting pedicels to $25 \mathrm{~mm}$ long and 3 , exceptionally to $10 \mathrm{~mm}$ diam, densely covered with appressed to erect, brown hairs, becoming glabrous, articulated at $1 / 3-2 / 3$ from the base, with 5-8 soon falling bracts; flower buds broadly ovoid, slightly apiculate; sepals free, broadly ovate-triangular, $8-11$ by $6-9 \mathrm{~mm}$, patent, but soon reflexed, outer side densely covered with appressed to erect, brown hairs; petals greyish red ('rojas grisáceas') to reddish brown, equal, oblong-elliptic, $10-18$ by $6-7 \mathrm{~mm}$, outer side densely covered with appressed to erect, brown hairs; stamens c. $1.5 \mathrm{~mm}$ long, connective shield glabrous. Monocarps 50-75, green, maturing brown to black in vivo, black in sicco, ellipsoid, $10-12$ by $4-5 \mathrm{~mm}$, glabrous, apex apiculate (apiculum to $1 \mathrm{~mm}$ long), wall c. $0.1 \mathrm{~mm}$ thick, stipes $4-15$ by $1 \mathrm{~mm}$. Seed ellipsoid, $8-9$ by $4-5 \mathrm{~mm}$, shiny brown, slightly pitted.

Distribution - Bolivia (Santa Cruz), Peru (Huánuco, Madre de Dios).

Habitat \& Ecology — In tropical to subtropical forest. At elevations of c. 200-400 m. Flowering: January, February, April, July, December; fruiting: August, October.

Vernacular names - Peru: Carahuasca (Tello 1734).

Note - Guatteria sanctae-crucis can easily be recognized by its long, oblong-elliptic leaves and by the larger distance between loops of secondary veins and the leaf margin (4-7 $\mathrm{mm})$, and by its large sepals up to $11 \mathrm{~mm}$ long.

Other specimens examined. BoLIVIA, Santa Cruz, Prov. Ichilo, Reserva Forestal Choré, Río Ibabo, Bosque Experimental 'Elias Meneces', 180 m, Neill \& Quevedo 9357 (U); Prov. Ichilo, Parque Nacional Amboro, Río Saguayo, 400 m, Saldias P. 150 (NY, U); Prov. Ichilo, Quebrada Yeso, near El Carmen, $8 \mathrm{~km}$ S of Buena Vista, 400 m, Saldias P. \& Flores S. 4916 (NY, U). - PERU, Huánuco, Distr. Yuyapichis, Prov. Puerto Inca, Dantas, April 1991, 25 m, Tello 1734 (MO). Madre de Dios: Prov. Manu, Río Alto Madre de Dios, near chacra of Sr. Carpio, halfway between Shintuya and Manu, Foster et al. 3247 (MO); prov. Manu, Parque Nacional del Manu, Cocha Cashu Station, 350 m, Foster 9601 (MO, NY); Tambopata, along Río Tambopata, 280 m, Gentry et al. $45893(\mathrm{U})$.

\section{Guatteria terminalis R.E.Fr. - Plate 2; Map 3}

Guatteria terminalis R.E.Fr. (1938) 709; (1939) 303, f. 2a-b. - Type: Lechler 2648 (holo UPS; iso B, G, K, LE, P), Peru, Puno, Tatanera ('Tatanara'), Aug. 1854.

Tree 8-12 m tall; young twigs rather densely to sparsely covered with appressed hairs, soon glabrous. Leaves: petiole 2-8 mm long, 0.5-1 mm diam; lamina narrowly elliptic, 4-9 by $2-3.5 \mathrm{~cm}$ (leaf index $2.2-2.7$ ), coriaceous, not verruculose, shiny, dark blackish brown above, dark brown below, glabrous above, sparsely covered with appressed, white hairs below, base long-attenuate, apex obtuse, acute, or shortly acuminate (acumen 3-7 mm long), primary vein flat to impressed above, secondary veins distinct, $7-12$ on either side of primary vein, strongly prominent above, smallest distance between loops and margin 1-2 $\mathrm{mm}$, tertiary venation reticulate, strongly prominent above. Flowers solitary, in leafy zone, terminal; pedicels 15-20 $\mathrm{mm}$ long, c. $1 \mathrm{~mm}$ diam, fruiting pedicels to $2 \mathrm{~mm}$ diam, rather densely to sparsely covered with appressed, white hairs; flower buds depressed ovoid; sepals free, broadly ovate-triangular, c. 5 by $5 \mathrm{~mm}$, outer side rather densely covered with appressed hairs; petals lead-coloured to yellow in vivo, equal, narrowly elliptic to narrowly obovate, $10-20$ by $4-8 \mathrm{~mm}$, outer side densely covered with appressed hairs; stamens 1-2 mm long, connective shield papillate. Monocarps 20-25, green, maturing purple-red ('morado') in vivo, ellipsoid, $12-15$ by $6-7$ $\mathrm{mm}$, sparsely covered with appressed hairs, apex apiculate (apiculum $<0.2 \mathrm{~mm}$ long), stipes $3-4$ by $3 \mathrm{~mm}$. Seed not studied (abortive?).

Distribution - Peru (Cuzco, Huánuco, Puno).

Habitat \& Ecology - Cloud forest, dominated by Cyatheaceae, Alzateaceae, Cunoniaceae and Myrtaceae, or low elfin forest with many epiphytic lichens, mosses, and ground covered by a thick layer of roots, rotten leaves, and mosses. At elevations of 1800-2300 m. Flowering: June, August, September; fruiting: August, September.

Note - Guatteria terminalis is unique by its lead-coloured flowers (at least in the Farfán collections) in combination with terminal flowers. Terminal flowers in Guatteria otherwise are only known in G. anomala R.E.Fr., G. grandiflora Donn.Sm. and $G$. acrantha Erkens \& Maas, all from Central America.

Other specimens examined. PERu, Cuzco, Prov. Paucartambo, Kosñipata, Trocha Unión, 1835 m, Farfán et al. 995 (only photographs seen: CUZ, DAV, HUT, MO, USM, WFU), idem, 2295 m, Farfán et al. 1112 (only photographs seen: CUZ, DAV, HUT, MO, USM, WFU). Huánuco: Prov. Pachitea, region of Pucallpa, W part of Sira Mts, 26-28 km ESE of Puerto Inca, 1995 m, Wallnöfer 17-20688 (U).

\section{Pseudoxandra xylopiifolia Maas \& Westra, sp. nov. — Fig. 10; Map 1}

Pseudoxandrae pilosae valde affinis sed foliis brevioribus et angustioribus Xylopiam simulantibus. - Typus: Graham 2447 (holo F; iso K, MO, NY, U), Peru, Ucayali, Prov. Coronel Portillo, Distr. Calleria, basin of Río Utiquinia, Quebrada Espjoyacu, affluent of Quebrada Manuela, 300 m, 23 July 2003.

Tree 12-15 $\mathrm{m}$ tall; young twigs densely covered with appressed hairs to $3 \mathrm{~mm}$ long. Leaves: petiole $2-3 \mathrm{~mm}$ long, c. $0.5 \mathrm{~mm}$ diam; lamina narrowly elliptic, $5-7.5$ by $3.5-5 \mathrm{~cm}$ (leaf index $3.5-5)$, chartaceous, densely verruculose, shiny green in vivo above, dark brownish green above, pale brownish green below, sparsely covered with appressed hairs, mainly along primary vein to finally glabrous above, rather densely to sparsely covered with appressed hairs to $3 \mathrm{~mm}$ long below, base acute, with distinct angular projections on either side, apex slightly acuminate (acumen 5-8 $\mathrm{mm}$ long) to acute, apex in young leaves often provided with a tuft of hairs to c. $3 \mathrm{~mm}$ long, secondary veins weakly distinct, straight, $15-20$ on either side of primary vein, alternating with intersecondary veins, slightly prominent above, angles with primary vein $80-90^{\circ}$, smallest distance of marginal vein from margin c. $0.5 \mathrm{~mm}$. Inflorescences 1-3-flowered (?), only seen with a single fruit, produced from leafless branches, peduncles 2-3 mm long, densely covered with appressed hairs; bracts 3 or more, broadly to depressed ovate, 3-6 mm long, outer side densely covered with appressed hairs; fruiting pedicels c. $5 \mathrm{~mm}$ long, $2.5 \mathrm{~mm}$ diam, densely covered with appressed hairs; sepals basally connate, depressed to very broadly ovate, $7-10$ by $10-12 \mathrm{~mm}$, outer side densely covered with appressed hairs; petals, stamens and carpels not seen. Monocarps 4-10, green in vivo, black in sicco, globose, 12-13 $\mathrm{mm}$ diam, apex apiculate (apiculum $0.1-0.5 \mathrm{~mm}$ long), wall c. $0.5 \mathrm{~mm}$ thick, stipes $0.5-2$ by $1-2 \mathrm{~mm}$; fruiting receptacle depressed ovoid, 4-7 mm diam. Seed subglobose, 10-11 mm diam, pale brown, slightly pitted.

Distribution - Amazonian Peru (Ucayali).

Habitat \& Ecology — In non-inundated, primary forest. At an elevation of c. $300 \mathrm{~m}$. Flowering: unknown; fruiting: July.

Notes - Pseudoxandra xylopiifolia, only known from the type collection, matches P. pilosa Maas by an indument of long, appressed hairs on most of its vegetative and fertile parts, but the leaves are much shorter and narrower $(5-7.5$ by $3.5-5 \mathrm{~cm}$ vs $16-20$ by $3-4 \mathrm{~cm}$ in P. pilosa).

The wood and bark of this species are reported to have a very strong aromatic scent. 


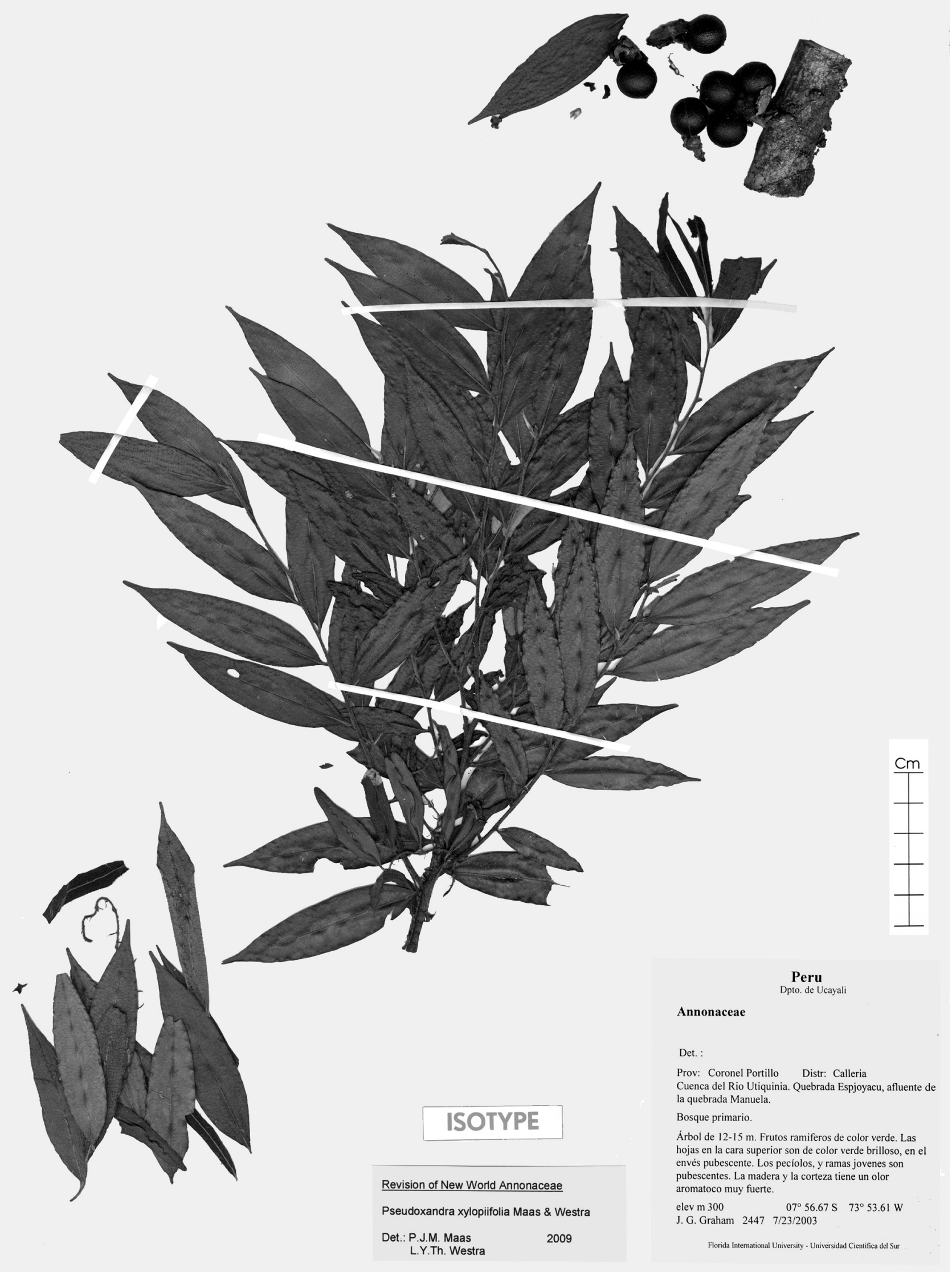

Fig. 10 Pseudoxandra xylopiifolia Maas \& Westra. Parts of fruiting branch (Graham 2447, iso U). 
Acknowledgements We thank Mr. William Farfán (CUZ, Peru) for providing us with unique photographs of the rare Guatteria terminalis and Mr. James G. Graham (F) for making available photographs of Pseudoxandra xylopiifolia. Furthermore we are indebted to the curators of the herbaria $\mathrm{COAH}, \mathrm{F}, \mathrm{MO}$, NY, S, U, US and VEN for sending material on loan.

\section{REFERENCES}

Diels L. 1906. Anonaceae andinae. In: I. Urban, Plantae novae andinae imprimis Weberbauerianae I. Botanische Jahrbücher für Systematik, Pflanzengeschichte und Pflanzengeographie 37: 408-410.

Diels L. 1924. Anonaceae. In: Mildbraed J, Plantae Tessmannianae peruvianae I. Notizblatt des Botanischen Gartens und Museums zu BerlinDahlem 9: 137-141.

Erkens RHJ. 2007. From morphological nightmare to molecular conundrum. Phylogenetic, evolutionary and taxonomic studies on Guatteria (Annonaceae). PhD thesis, Utrecht University.

Erkens RHJ, Chatrou LW, Koek-Noorman J, Maas JW, Maas PJM. 2007a. Classification of a large and widespread genus of Neotropical trees, Guatteria (Annonaceae) and its three satellite genera Guatteriella, Guatteriopsis and Heteropetalum. Taxon 56: 757-774.

Erkens RHJ, Chatrou LW, Maas JW, Van der Niet T, Savolainen V. 2007b. A rapid diversification of rainforest trees (Guatteria: Annonaceae) following dispersal from Central into South America. Molecular Phylogenetics and Evolution 44: 399-411.

Erkens RHJ, Maas PJM. 2008. The Guatteria group disentangled: sinking Guatteriopsis, Guatteriella, and Heteropetalum in Guatteria. Rodriguésia 59: 401-406.

Erkens RHJ, Maas PJM, Chatrou LW, Zamora N. 2006. Seven taxonomic discoveries in Annonaceae from southeastern Central America. Blumea 51: $199-220$.

Erkens RHJ, Westra LYTh, Maas PJM. 2008. Increasing diversity in the species-rich genus Guatteria (Annonaceae). Blumea 53: 467-514.
Fries RE. 1938. Annonaceae. In: Macbride JF, Flora of Peru. Field Museum of Natural History, Botanical series 13, 2: 700-766.

Fries RE. 1939. Revision der Arten einiger Annonaceen-Gattungen. Acta Horti Bergiani 12: 289-540.

Fries RE. 1947. Die Annonaceen der vierten Regnellschen Expedition. Arkiv för Botanik 33A(9): 1-20.

Fries RE. 1957. New species of Annonaceae from the Upper Amazon Basin, Arkiv för Botanik, n.s. 3, 18: 601

Maas PJM, Westra LYTh. 2003. Revision of the Neotropical genus Pseudoxandra (Annonaceae). Blumea 48: 201-259.

Maas PJM, Westra LYTh. 2005. A new species of Pseudoxandra. Blumea 50: 61.

Maas PJM, Westra LYTh, Chatrou LW, Various Collaborators. 2003. Duguetia (Annonaceae). Flora Neotropica Monograph 88: 1-274.

Maas PJM, Westra LYTh, Various Collaborators. 1992. Rollinia (Annonaceae). Flora Neotropica Monograph 57: 1-188.

Rainer H. 2007. Monographic studies in the genus Annona L. (Annonaceae): Inclusion of the genus Rollinia A. St.-Hil. Annalen des Naturhistorischen Museums in Wien, Serie B, Botanik und Zoologie 108B: 191-205.

Ruiz López H, Pavón JA. 1798. Systema vegetabilium florae peruvianae et chilensis 1: 144-146. Madrid, typis Gabrielis de Sancha.

Scharf U, Maas PJM, Morawetz W. 2005. Five new species of Guatteria (Annonaceae) from the Pakaraima mountains. Blumea 50: 563-573.

Scharf U, Maas PJM, Morawetz W. 2006a. Five new species of Guatteria (Annonaceae) from French Guiana, Guyana, and Suriname. Blumea 51: 117-130.

Scharf U, Maas PJM, Morawetz W. 2006b. Guatteria richardii (Annonaceae) rediscovered along with two new species from French Guiana. Blumea 51: 541-552.

Scharf U, Maas PJM, Prévost MF. 2008. An unusual new species of Guatteria (Annonaceae) from French Guiana and adjacent Brazil (Amapá). Blumea 53: 515-523.

Van Setten AK, Maas PJM. 1990. Studies in Annonaceae. XIV. Index to generic names of Annonaceae. Taxon 39: 675-690.

\section{IDENTIFICATION LIST}

The abbreviations after the collector numbers refer to the following taxa:
Ann oxa
Dug vau
Gua cas
Gua den

\begin{abstract}
Gua gla
\end{abstract}
- Guatteria glauca

Gua mod = Guatteria modesta

Gua modp = Guatteria modesta - see

'Notes' under Guatteria modesta

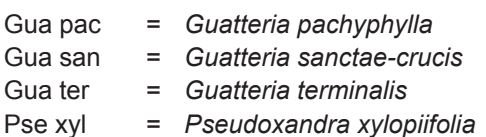

Acevedo-R. et al. 9082: Gua gla - Alexiades et al. 193: Gua mod - Altamirana et al. 2457, 3288: Gua gla - Alvarez et al. 1788: Gua gla-Antezana et al. 456: Gua gla - Apaza et al. 843, 945, 947: Gua gla - Araujo, A. et al. 37: Gua gla - Araujo-M., C. et al. 2989: Gua gla - Araujo-Murakami, A. et al. 3203, 3273, 3336: Gua gla - Arias et al. 428: Gua gla - Arostegui V. et al. 127: Gua modp - Aspajo V. 15: Gua mod - Aulestia et al. 313: Gua mod; 366: Gua gla; 631, 637, 730, 922, 1251, 1445, 1752, 3041, 3551: Gua mod

Barbour 5429: Gua gla - Bascopé et al. 107: Gua gla - Beck et al. 13956, 18521, 20788, 24416, 28303: Gua gla - Beltran \& Foster 282, 1009: Gua gla - Bolivia 171: Gua gla - Boom \& Beardsley 8455: Gua gla - Bourdy 1740: Gua gla - Buchtien 701, 7296: Gua gla.

Cahuaya \& Gonzales 12: Gua gla - Calatayud et al. 2021, 2672, 3083, 3324: Gua gla - Campbell et al. 6394: Gua modp; 9694: Gua gla - Campos et al. 3055, 3786, 3881, 4269, 4634, 5529, 6274, 6520: Gua gla - Cárdenas et al. 831: Ann oxa - Castillo S. 1425: Gua den; 5157: Gua pac; 5444, 6848, 6960: Gua cas - Cayola et al. 1113, 2396, 2430, 2680: Gua gla - Cerón et al. 460: Gua gla; 2911, 3466, 7486; 8420, 9186: Gua mod; 9221: Gua modp; 20720, 20901: Gua gla; 21161: Gua mod - Chapi et al. 38: Gua gla - Chatrou et al. 172, 252: Gua mod; 324, 328, 414, 415, 434, 445, 461: Gua gla - Cid et al. 5104, 5300: Gua gla - Clark, J.L. et al. 3321, 6698: Gua gla - Colque et al. 203, 256, 369, 733, 734: Gua gla.

Daly et al. 6878: Gua gla; 7729, 9126: Gua mod - De Michel, R. et al. 590, 672, 757: Gua gla - De Walt et al. 121: Gua gla - Defler 12: Dug vau - Díaz et al. 7230: Gua gla; 7370, 7390: Gua mod - Dik et al. 147, 257, 879, 905, 1583: Gua mod

Encarnación 1042: Gua mod - Espinoza et al. 216, 617: Gua mod.

Farfán et al. 995, 1112: Gua ter - Fernandez Casas \& Susanna 8075: Gua gla - Flores \& Tello 90: Gua mod - Foster, P.F. et al. 466: Gua gla - Foster, R. 3247, 9601: Gua san - Freire et al. 3108, 3210, 3392: Gua mod; 3431, 4376: Gua gla - Fuentes et al. 5917, 7239, 7506, 7551, 9042, 9327, 11254, 11444, 11632: Gua gla.
Galiano et al. 6818: Gua gla - García et al. 367: Gua gla - Gentry et al. 27918, 41388: Gua mod; 41991: Gua gla; 42224: Gua modp; 43016: Gua mod; 44660: Gua gla; 44915: Gua mod; 45893: Gua san; 54579: Gua modp; 54936: Gua mod; 61788: Gua modp; 71005: Gua gla; 76350: Gua mod; 77425: Gua modp - Graham 2377: Gua modp; 2447: Pse xyl - Grández 2856: Gua modp - Gudiño et al. 214: Gua gla; 824: Gua mod - Guillén et al. 2494, 4131: Gua gla - Gutiérrez R. et al. 206, 468, 1351: Gua gla.

Harling \& Andersson 24349: Gua gla - Helme 406: Gua gla - Homeier et al. 619, 2367, 2444, 2600: Gua gla; 2853, 2877: Gua mod - Huashikat 879, 2161: Gua mod - Hurtado 621, 1320: Gua mod.

Jaramillo et al. 421: Gua gla; 688: Gua mod - Jordán 296: Gua gla - Jørgensen et al. 2304, 56492: Gua gla.

Kajekai et al. 201: Gua gla; 551: Gua mod; 756: Gua gla - Katan et al. 27, 130, 201: Gua gla - Kayap 232: Gua mod; 395: Gua gla; 850: Gua mod - Killeen et al. 2917, 3571, 4305, 4308, 4326, 4866, 6177, 7442: Gua gla - Killip \& Smith 23975, 24877, 24949: Gua gla - King et al. 975: Gua modp - Kinzey 276: Gua mod - Klitgaard et al. 348: Gua gla - Knapp et al. 7447: Gua gla - Korning \& Thomsen 58619: Gua mod - Kröll 197, 228: Gua mod - Krukoff 5253: Gua gla; 8225: Gua modp; 8381: Gua mod; 10163, 10543, 10831, 11027, 11086, 11214: Gua gla.

Lechler 2648: Gua ter - Leiva G. et al. 1600: Gua gla - Lowrie et al. 561: Gua gla - Loza et al. 289: Gua gla - Lugo S. 237, 3392, 3424: Gua mod.

Maldonado et al. 223, 2210, 2634: Gua gla - Meneces 2087, 2336: Gua gla - Monteagudo et al. 3552, 3591, 4325, 5488, 5492, 5719, 5906, 11944: Gua gla; 6949: Ann oxa; 7612, 7678: Gua gla - Montero \& Divico 351: Gua gla.

Nee 37331: Gua san; 40987, 41243, 50246: Gua gla - Neill et al. 8206: Gua mod; 9000: Gua modp; 9344: Gua gla; 9357: Gua san; 13144, 14041 , 14135, 14225, 14261, 14656, 15010, 15162, 15313, 15777, 15781, 16214, 16225, 16231: Gua gla - Nelson et al. 836: Gua gla - Nuñez 5602, 11194, 12100: Gua gla.

Orellana et al. 1302, 1783, 1802: Gua gla - Ortega U. 24: Gua gla - Ortiz et al. 217: Gua gla. 
Palacios 1049: Gua mod; 1827: Gua gla; 3110, 3394, 3569, 4324, 4449: Gua mod; 4539, 4600: Gua gla; 4657, 4791, 4817, 4939: Gua mod; 6553: Gua gla; 7832, 10702: Gua mod; 13286, 13432: Gua gla - Panfil 139, 156: Gua gla - Peña \& Foster 105: Gua gla - Pennington, R.T. et al. 45, 1157: Gua gla - Pennington, T.D. et al. 17071: Gua mod - Perea et al. 50, 79: Gua gla; 371: Gua mod; 489: Gua gla; 1688: Ann oxa; 1564, 1596, 1907, 2258, 2362, 2445, 2647: Gua gla - Perry et al. 433, 1000: Gua gla - Pipoly 12964, 14106: Gua modp - Pirie et al. 39, 88, 93, 110: Gua gla; 135: Gua mod - Pitman 627: Gua mod - Prance et al. 5716, 6055: Gua gla.

Quevedo et al. 920: Gua gla - Quizhpe et al. 205, 212, 827, 1878, 2527: Gua gla.

Rea \& Kuno 369: Gua gla - Revilla 3626: Gua pac-Reyna R. 62: Gua mod - Reynel et al. 5053, 5101, 5602: Gua gla - Rodríguez et al. 748, 2931, 3117: Gua gla - Rojas et al. 150: Gua mod; 2801, 3039: Gua gla - Ruíz 1193: Gua mod - Rudas et al. 3656: Gua modp - Rusby 1252: Gua gla. Saldias P. et al. 150, 4916: Gua san - Sánchez Vega et al. 8350, 8464, 8486, 8493, 8622, 8922: Gua gla; 9344: Gua mod; 9448, 9450, 9521, 9611, 10367, 11227: Gua gla - Schultes \& Cabrera 17374, 17542: Gua den - Schunke, C. A97: Gua gla - Schunke V., J. 857, 6583, 9334: Gua gla - SEF (Studies of Ecuadorean Forests) 10075: Gua mod - Seidel et al. 5795: Gua gla - Serato 58: Gua gla - Silveira et al. 713: Gua gla - Smith, D.N. et al. 1491, 1549, 2938, 3895, 4628, 5148, 5462A, 5747, 6909, 8577,
8619, 13252, 13749, 14128: Gua gla - Solomon 7981, 9252, 9269, 9616 10824, 12964, 14869, 17713A: Gua gla - Soria S. 11: Gua mod - Soto et al. 395: Gua gla - Sperling \& King 5539: Gua gla - Stergios et al.11488: Gua pac - Suclli et al. 1033, 2739: Gua gla.

Tello 1711, 1733: Gua mod; 1734: Gua san - Tessmann 3423, 3476, 4314: Gua mod - Timaná 863, 914, 1134, 1231: Gua gla - Toasa 8921: Gua gla - Tunqui 194: Gua mod.

Valenzuela et al. 685, 736, 2810, 5192, 6804, 6961, 7239: Gua gla - Van der Werff 10162: Gua mod; 13208, 15445, 15632, 16499, 16944, 17520, 17523, 17673, 17712, 18979, 19527, 21457, 21971: Gua gla - Vargas, H. et al. 569, 873: Gua mod - Vargas, L. et al. 979: Gua gla - Vargas C., I.G. et al. 675, 3748, 3760, 5323, 6547: Gua gla - Vásquez et al. 465: Gua pac; 2734: Gua mod; 5530: Gua pac; 8747, 12631: Gua mod; 12929, 14407, 15566, 17535, 20358: Gua modp; 20442: Gua gla; 21354: Gua modp; 21877: Gua gla; 23348: Gua modp; 25336, 25371, 25751, 26150, 26621 27380, 27445, 28309: Gua gla; 28355: Ann oxa; 29223, 29494, 29770 : Gua gla; 30470, 30476: Ann oxa; 30535: Gua gla.

Wallnöfer 11-30188, 14-29488, 16-28488: Gua gla; 17-20688: Gua ter; 110-040188: Gua gla - Weberbauer 3548: Gua gla - White 2064: Gua gla - Wisum et al. 40, 775: Gua gla - Woytkowski 6218, 6387: Gua gla.

Zak \& Espinoza 4061: Gua modp; 4390, 4531, 4567, 4596, 4724, 4738, 4746, 5106: Gua mod - Zenteno et al. 1423, 3078: Gua gla - Zuleta 134: Gua mod.

\section{INDEX TO SCIENTIFIC NAMES}

Accepted taxa are in roman type, new taxa in bold, and synonyms in italics. Numbers refer to the species number as used in this article.

Annona

oxapampae Maas \& Westra 1

Duguetia

vaupesana Westra \& Maas 2

Guatteria

buchtienii R.E.Fr. 5

chlorantha Diels 6

castilloi Maas \& Westra 3

coeloneura Diels 5
Guatteria (cont.)

denudata R.E.Fr. 4

geminiflora R.E.Fr. var. geminiflora 6

glaberrima R.E.Fr. 6

glauca Ruiz \& Pav. 5

juninensis R.E.Fr. 5

lasiocalyx R.E.Fr. 5

modesta Diels 6

\author{
Guatteria (cont.) \\ pachyphylla Maas \& Westra 7 \\ pleiocarpa Diels 5 \\ puncticulata R.E.Fr. 6 \\ rhamnoides R.E.Fr. 5 \\ sanctae-crucis Maas \& Westra 8 \\ terminalis R.E.Fr. 9 \\ Pseudoxandra
}

xylopiifolia Maas \& Westra 10 